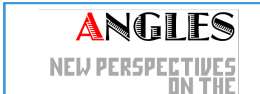
ANELOPHONE WORLD

\section{Angles}

New Perspectives on the Anglophone World

$4 \mid 2017$

Unstable States, Mutable Conditions

\title{
Idiosyncrasies of the 2010 Affordable Care Act from a Comparative Perspective
}

\section{Lea Stephan}

\section{(2) OpenEdition}

1 Journals

\section{Electronic version}

URL: https://journals.openedition.org/angles/1598

DOI: 10.4000/angles. 1598

ISSN: 2274-2042

\section{Publisher}

Société des Anglicistes de l'Enseignement Supérieur

\section{Electronic reference}

Lea Stephan, "Idiosyncrasies of the 2010 Affordable Care Act from a Comparative Perspective", Angles [Online], 4 | 2017, Online since 01 April 2017, connection on 07 June 2022. URL: http:// journals.openedition.org/angles/1598 ; DOI: https://doi.org/10.4000/angles.1598

This text was automatically generated on 7 June 2022.

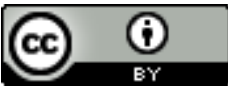

Angles est mise à disposition selon les termes de la Licence Creative Commons Attribution 4.0 International. 


\title{
Idiosyncrasies of the 2010 Affordable Care Act from a Comparative Perspective
}

\author{
Lea Stephan
}

1 The Affordable Care Act passed by the US Congress in 2010 has been criticized for many of its shortcomings. However, a policy choice does not emerge in a sterile environment; it originates in a particular context and is deeply influenced by society and culture (Goodin 289), which explains why it is never the objectively best solution that is chosen, but a solution that works in a given context. Comparative political science is an efficient way of assessing particularities due to a specific context (Van Woodward 9, 17). By examining the differences and similarities between two countries on a given issue, the contextual particularities that shaped each policy can emerge. When looking at issues that seem to converge across Western countries, such as cost-control and insurance systems, such a comparison highlights the divergence. Similar conditions are often expected to lead to similar policy choices, but choices are deeply shaped by social, cultural, and political values (Blank and Burau 265, 280).

In a comparative approach of social policies, the distinctiveness of the American system has often been highlighted. For example, among the health systems of the postindustrial world, the US stands out because of its heavy reliance on the private market to address health care needs (Gerliner and Burkhardt; Evans 135-6, 141). ${ }^{1}$ These specificities have often been explained in terms of typically American values: individual freedom, personal responsibility, and small government (Gilens 1). More recently, however, it has increasingly been argued that American social policies are deeply racialized and that systemic racism has strongly contributed to the shaping of the American welfare state (Edsall). The comparative approach obviously has its limits. Sociologist and political scientist Theda Skocpol, for example, discards a purely comparative analysis of US social policies. According to her, the comparative perspective alone, without an in-depth analysis of the historical development of social 
policies in the US, does not allow for a satisfying explanation of this racialization of social policies that occurred in the US (Skocpol 12).

3 Nonetheless, comparisons with other countries are useful to put forward the specificity of the racial context of the United States in showing how the issue evolved in countries where discourse is not deeply stained by racial conflict. Therefore, comparisons will be made with health care policies in Europe, from their origins in Germany in 1883 to today and in a range of countries, with a focus on Germany, the United Kingdom, and France. Comparisons with Canada will be made as well, notably because of its geographical proximity and frequent use as example of a health care system that 'works'. Regrettably, systematic comparisons are not possible, so comparisons will be made in a way as to most effectively highlight salient differences.

We will first give a brief overview of the development of health policies in the US, then we will expose the major flaws of Medicare-Medicaid. Finally, we will examine Obama's health care reform, the Affordable Care Act (ACA), to reveal the peculiar aspects directly influenced by the historical and racialized development of American social policies.

\section{A Brief Historical Overview of Health Policy Development}

5 It is commonly assumed that social policies were only developed in the US during the 1930s with President Roosevelt's New Deal programs. However, there is a far older American Welfare State. Early American social policy developed at local, state, and federal levels. Those programs involved benefits for Civil War veterans, an inclusive primary and secondary school system, and some benefits for widows and orphans, which were further developed in 1910. The proportions should not be overlooked: early social policies mostly benefited elderly white men in the North (Skocpol 12; Fording and Schram 54-7).

6 Regarding health insurance at the turn of the 20th century, the US was not initially lagging behind other industrialized countries. Germany had passed pioneering health legislation in 1883, and both the US and the UK were contemplating more social policies in the 1910s. In Washington the idea of national health insurance made some headway but failed by 1920 (Howard 60).

7 The European model clearly inspired the US in envisaging comprehensive social policies, but all those European states had a strong government to take action in those matters. In the United States, however, the Progressive Era of the 1910s must be understood in relation to its "19th century patronage democracy": local systems disbursed social benefits to expand and maintain their constituencies, hence social benefits were associated with corruption, especially through veterans' pensions. The system covered many more people than there were actual veterans: about $1 / 3$ of the native-born men in the North received a pension. There was a willingness to rework this system into universal coverage for old age and disability but attempts by the Wilson administration to expand social policies were hampered by the association between social benefits and political corruption (Skocpol 141-4).

Shortly after the 1912 elections, in which Theodore Roosevelt ran on a platform including health insurance, health care legislation was promoted by a group of academics and the American Association for Labor Legislation. Although their proposal 
was rather conservative and would only have covered workers (domestic and casual workers excluded), ${ }^{2}$ their proposal was strongly opposed by labor unions because of their strong distrust of government, but even more because unions provided this type of benefits for their members and feared the competition (Patel and Rushefsky 39). Insurers opposed the proposal as well because they viewed it as a government assault on private enterprise. After World War I, opposition to health legislation grew stronger, because it had its origins in the much-hated German nation (Starr 30-5).

Although there were advocates of universal health coverage prior to World War I, strong opposition developed as well. Because of the medical progress made during the 1920s, opposition to compulsory insurance emerged. Opponents such as the American Medical Association feared that the government would set limits and issue regulations that would hamper their opportunity of making greater profits from health services, especially from middle-class patients who were attracted by medical progress. At the same time, France debated the expansion of social protection. Small business notably opposed those ideas because they feared cost increases (Elbaum 30).

During the New Deal, President Roosevelt showed great interest in establishing health insurance but "political realities", namely opposition from Republicans and Southern Democrats with the support of lobbies like the American Medical Association (AMA), prevented it (Katz 258).

During the same period, and partly fuelled by Roosevelt's New Deal, Canada attempted to introduce comprehensive, national health care, but the government's proposal was defeated (Boychuck 34-5, 37-8).

Truman introduced health care reform twice, in 1945 and 1949, and was defeated both times. Although the New Deal had been under attack from the beginning, Truman remained openly very supportive of the Welfare State principle and the New Deal. Just like Roosevelt's plan, Truman's attempts to establish national health care were attacked as socialism (Morone and Blumenthal). This seems particularly ironic from a comparative perspective, since one of German Chancellor Otto von Bismarck's motives in enacting health care was to weaken the appeal of German socialists (Blackbourn 346). ${ }^{3}$ Similar motives were at work in France, but they only found hesitant expression in the 1880s and 1890s (Elbaum 30). ${ }^{4}$ The Truman health program planned for national health coverage run and funded by government (Truman 2015). But out of respect for American love of freedom, the program would have been optional. Political scientist Gerard Boychuck argues that Truman's health reforms were opposed and defeated because they were openly linked to the administration's desegregation efforts (Boychuck 41).

13 While Truman's health care bills were defeated in the US, France started developing a comprehensive health care system in 1945 (Valtriani 11). Contracting health care insurance became mandatory, but the system was mixed: only part of the coverage is run by government (Elbaum 7). ${ }^{5}$

14 As mentioned earlier, opposition rhetoric equating universal and national health care with socialism was among the forces preventing the creation of legislation in the US. Hence, as early as the 1950s, health care advocates started shifting their discourse, focusing more on health care for the elderly because it had greater political appeal (Katz-Olson 22). In comparison, in the UK, the National Health Service was created in 
1948 as a state-administered system of universal coverage, funded through general revenue and free at point of service (Powell).

The accusations of "socialized medicine" are still used in conservative rhetoric today, but are rooted in the periods opposing the Soviet regime and Nazi Germany. According to sociologist and political scientist Paul Starr, this opposition is a unique feature of American thinking: "Only in the United States is public responsibility for health-care costs equated with a loss of freedom." (Starr 9-10) However, according to Boychuck, the "socialist" rhetoric can also be read in a more racialized manner, especially since Truman's health care efforts were closely linked with his civil rights agenda. The opposition had remained the same since the Roosevelt attempt. Support, however, was shown by the National Association for the Advancement of Colored People and the black National Medical Association. According to Boychuck, the language used to oppose civil rights matched the language used to oppose health care. The phrase "socialized medicine" especially pointed to a threat to segregation, the most potent item being the issue of doctor choice, in both directions, patient-doctor and doctorpatient. The accusation of socialism can be considered the "easiest and most common approach to opposing any progressive social legislation" (Boychuck 44, 47, 50).

The next attempt at achieving major social reform came in the 1960s with the election of John F. Kennedy. A new window of opportunity for reform opened, as it had for FDR. ${ }^{6}$ Kennedy faced the choice of moving toward the center and diminishing possible resistance from conservatives and big business, or to make a bolder move on the left. Even more so than FDR had done, Kennedy chose to show himself "extremely conciliatory with the economy." (Noble 90) Kennedy chose a more conservative approach, dropping the reform of the tax code and abandoning plans to increase social spending by 1962, and opting for tax cuts to stimulate the economy. The Kennedy administration adopted the domestic policy agenda already established by Congressional Democrats, among which figured health care for the aged and the poor. But when conservatives blocked the proposals, Kennedy, who was "uninterested in domestic policy and put off by the need to court congressional leaders in order to pass domestic legislation," simply focused his attention on other issues (Noble 91).

Finally, it was president Lyndon B. Johnson's commitment to social issues, his savviness in dealing with Congress, and his ability to use political momentum that allowed him to push for health care legislation. It must be noted that Johnson did more than just enacting Kennedy's projects: he redefined the proposals and pushed for more ambitious legislation (Jansson 243; Feagin 73; Noble 93).

Johnson faced mixed conditions for enacting legislation. The economy was booming, making it difficult for conservatives to mobilize business opposition; in fact, business was rather supportive of new social policies (Noble 82-3). The situation was similar when Bismarck first enacted social policies in Germany, as business had been a driving force, recognizing their advantage in a healthier and more secure workforce (Blackbourn 346). ${ }^{7}$ But Southern Democrats, Unions, and Federalism took their toll on the new health care system.

The New Deal had set the precedent for a "two-track system" through Social Security and public assistance targeting only the elderly and the very poor (Noble 79). This way of proceeding precluded any universalist approach, and made it subsequently more difficult to argue for universal programs. ${ }^{8}$ It should come as no surprise that the 1965 health care legislation, envisaged as a temporary step toward universal coverage, 
should have matched the system set by the New Deal: Medicaid for the poor and Medicare for the elderly. Although the Medicare proposal received broad public support, the Medicaid part of the legislation was designed secretly by Johnson and Wilbur Mills, then Chairman of the House Ways and Means Committee (the main committee with jurisdiction over health issues). The final proposal came as a surprise to Congress and Johnson's role in it has long been downplayed, although, according to Mills, Johnson's involvement was crucial in achieving the legislation (Morone and Blumenthal 164-5, 166, 194). Medicare was especially opposed by the American Medical Association and the insurance industry (Noble 88). Although they had lost power in Congress, Southern Democrats were still fierce opponents of any universalist approach and any improvement of social policies because they feared that their system of racial segregation could be threatened, but they feared especially that any improvement of the living conditions of poor blacks would make it more difficult to maintain their exploitation system and very low wages (Soss et al. 57; Noble 89).

Federalism is yet another American feature that shaped the health system. The most striking comparison can be made with Germany, since the two countries have a similarly federal structure. Bismarck chose to create a centralized health care system (Blackbourn 347). However, this must be qualified. Although it is a centralized system, the government only issues guidelines to be implemented by private, state-supervised insurance companies (Gerlinger and Burkhardt). ${ }^{9}$ The development in the US was slightly different. In the American system, administration of social and public health care programs is divided between federal and state governments. This depends on the programs, and some programs are shared between the federal and state levels. The administration of health programs will be detailed later, but this sharing of programs gives states greater freedom in administering certain programs. Usually, the more conservative states have weaker social programs.

One of the most American features in the battle for social policies is the role played by unions. In Europe, unions and working class alliances were among the driving forces for the expansion of social policies. In the United States, on the contrary, unions were initially among the forces hampering the expansion of the Welfare State. The situation was complex because unions supported liberal political coalitions, but only for propositions that were feasible in the short term and of immediate interest to organized workers. They often opposed greater expansions of social policies, because the working class and the unions were greatly weakened by racial divisions. Their refusal to integrate minorities prevented them from developing their base and also made them more reluctant to support social policies that would have benefited all workers, including blacks. Moreover, they felt that their privileges were threatened through social policies, and were particularly wary of work-training programs that would increase competition (Noble 85-8; Feagin 51). ${ }^{10}$ In short, racial divisions among the American working class prevented them from supporting meaningful universal social reform, ultimately leading to narrowly-tailored programs, especially for the health care of the poor.

A growing body of scholars has been arguing that divisions among liberal Democrats on these issues have been deepened by conservative Republicans by racializing the social policy issue. Political scientists Paul Sniderman and Edward Carmines argue that racial issues, especially race-specific policies, are more divisive on the left than on the right. Conservative Republicans do not need any racist motivation to oppose social policies; 
they oppose any government intervention out of ideological principle. Democrats, on the contrary, can effectively be divided using racialized rhetoric. Initial support for social policies can be undermined by showing that it benefits minorities and thus opposition can be fostered among more racially conservative Democrats (Sniderman and Carmines 44-6, 78) or Democrats elected in more conservative districts or who have white working class constituencies. Since the 1970s, conservative Republicans constructed this racialized rhetoric as follows: the Democratic Party is portrayed as catering exclusively to minority interests, ignoring claims of the white working and middle class. In this view, social programs are presented as taxing hard-working whites to finance government outlays for underserving minorities who lack any work ethic and live immoral and lazy lives. ${ }^{11}$

At the same time as the US enacted Medicaid-Medicare, Canada managed to introduce in 1966 comprehensive national health care, supplanting the previous province-byprovince system. Canada's national health care efforts had also been hampered by issues of federalism. However, the creation of the Canadian Medicare (which has the same name as in the United States, but which refers to health care for everyone in the Canadian system) was questioned not because of underlying racial concerns but because of a discussion on the scope of the prerogatives of the federal government. Moreover, according to Boychuck's analysis, opposition by the French-speaking minority of Quebec hampered national health care. However, the conservative government elected in 1957 pushed for federal-provincial reconciliation and saw "national health care as a powerful tool for territorial integration." ( Boychuck 118-9, $124,125)^{12}$

In the US, Johnson managed to create a first public health care system in 1965 by adding title XX in the amendments to the Social Security Act. Medicare, the health program for the elderly, is based on an insurance concept to avoid any association with "socialism." It is financed through employer and employee payroll taxes. Despite the fact that it is partly funded by general revenues and is not exclusively contributory, people associate Medicare with an earned right (Katz-Olson 214). Only Medicare Part A covering hospital and limited nursing home care is funded by payroll taxes. Part B is funded by general revenues and beneficiary copayments and covers physician fees and other services. Part B was made optional under pressure from Republicans and the AMA. They also obtained the dropping of any cost-control measure, which led to inflating health costs (Starr 46, 48). According to political scientist James Morone and health care expert David Blumenthal, the issue of segregation shortly jeopardized the implementation of Medicare. Title VI of the 1964 Civil Rights Act forbids discrimination of any kind for programs that receive federal assistance. This meant that hospitals receiving Medicare payments could not segregate. Towards the end of 1967, all but a dozen hospitals in the South had implemented desegregation rather than losing Medicare funds. President Johnson's plan of using Medicare as a means for achieving social change had worked (Morone and Blumenthal 195-7).

Medicaid, on the other hand, which was hastily added as Title XIX to the Social Security Act, was constructed as "a conservative, sparse, uneven, and stigmatized program." It is based on a means test and funded "only by dint of national and state officials' annual good will." (Katz-Olson 24-6) It has to be highlighted that Medicare is centralized, whereas the funding and administration of Medicaid is split between the federal government and the states. In this sense, the latter happily combines demands of 
Southern Democrats with American federalism: the political system is used to satisfy the need of racial conservatives to maintain their black population in poverty by leaving to the states the administration and regulation of programs destined to the poor. And because of this joint administration, the implementation of Medicaid took much longer. By 1969, Arizona and Alaska still had not adopted Medicaid. As early as 1967, federal funding had been seriously capped: the federal government set the maximum eligibility levels that would receive federal funding. States were free to set higher levels, but none did (Katz-Olson 31). ${ }^{13}$

Thus health legislation as enacted by the Johnson administration was shaped by a very "American" political context that differed greatly from the situations obtaining in Europe. Political traditions and a unique situation of racial division of the working class prevented the creation of a comprehensive health care system, leading to Johnson's partial solution that proved lasting and resistant to reform, a solution which was flawed from its inception and laid the foundations for future problems and inequalities.

\section{A flaw-ridden public system}

The first flaw is soaring health care costs that have become a central problem of the American health care system. Medicare contributed to medical inflation because the program contained no cost-control measures. The program did not contain incentives for medical providers to decrease their charges or to refrain from unnecessary surgeries or treatments. In the case of Medicaid, open-ended entitlement had been capped rapidly, especially since federal spending had to match state spending, leading some states to soaring expenses due to generous coverage of their population (Jansson 248-9). ${ }^{14}$ Subsequent Medicaid reforms have led to a greater shifting of costs to the states and enactments of block grants in some areas, leading to increasing eligibility restrictions (Jansson 304). ${ }^{15}$ No cost-reducing incentive was built into Medicare, however, leading to soaring costs, caused only in part by evolving technology (Jansson 248). Before the introduction of diagnostics-related groups in Medicare to finance Medicare's hospital fees in 1983 under president Reagan, Medicare cost control was ignored at two levels (Jansson 304, 320). To ensure the AMA's collaboration, Wilbur Mills had promised that doctors, even within hospitals, could charge their private praxis fees on Medicare, thus making the program far more expensive (Morone and Blumenthal 194). In addition, Medicare was reimbursed on a fee-for-service basis that encouraged the multiplication of tests and procedures contributing to an increasingly costly system (Starr 48). Bluntly put, Medicare had become a means for the health care industry to milk the federal government.

The Balanced Budget Act of 1997 introduced Medicare Part C, providing Part A and B benefits through subsidized private insurance plans. Once more, a Democratic President, Bill Clinton, did the work that Republicans had not managed to achieve. ${ }^{16}$ Eventually, it was president George W. Bush who managed to further reform Medicare, where Reagan had failed. The 2003 Medicare Prescription Drug, Improvement, and Modernization Act moved ever more Medicare beneficiaries to the private insurance market. It also introduced Medicare Part D that covers prescription drugs on a subsidized and voluntary basis (Office of Retirement...; Howard 31). But both additions also had major flaws and would prove costly for both the beneficiaries and the taxpayers. This dismantling of the Welfare State, be it through privatization or through 
reducing programs into temporary assistance, shows the enduring nature of Reagan's ideological heritage. ${ }^{17}$ Something similar happened in the UK. Prime Minister Margaret Thatcher did not achieve fundamental health care reform, although it must be mentioned that funding was significantly cut under her leadership. It was the 2012 Health and Social Care Act that finally extended privatization to half of the NHS hospital beds. As with Reagan, the Thatcher legacy proves a lasting one and has fundamentally altered and shaped the discourse about taxes and social policies (Dorling 241; Walker 297).

Medicare Part D contained the infamous and expensive "doughnut hole": beneficiaries had to pay $1 / 4$ of the drug costs between $\$ 250$ and $\$ 2,250$, all of the cost from $\$ 2,550$ to $\$ 5,100$, and $5 \%$ of the cost above that amount. Additional insurance for the doughnut hole could not be purchased, thus making it a further incentive for the elderly to move on to private insurance rolls. These incentives had already been increased by the transformation of Part $\mathrm{C}$ into Medicare Advantage. However, these government subsidized private plans were yet another means for private companies to get more money out of the government: on average, those plans cost $\$ 1,000$ more per person per annum than a traditional Medicare coverage (Starr 149-50).

At the inception of Medicare, the AMA had pressured government into allowing physicians to charge higher fees than what was covered, leaving beneficiaries sometimes with high copayments. Combined with the "scanty" coverage provided by traditional Medicare (Office of Retirement...), ${ }^{18}$ many elderly are forced to an alternative tactic in case of serious illness and need of chronic nursing home care: the depletion of assets that allows them to move on to the Medicaid rolls (Jansson 248). These persons are referred to as dual-eligible beneficiaries. This creates yet another problem: these elderly persons inflate the costs of Medicaid, but, in the public mind, they are covered by Medicare, which is perceived as "earned" benefits. The costs of Medicaid, however, are among the constant arguments to restrict eligibility and to create measures for cutting the rolls. These measures usually affect people who are not responsible for the high costs (Katz-Olson 213). This way, the problem of Medicare costs became a major problem for Medicaid, since this makes the program more vulnerable.

But Medicaid's vulnerability also stems from the way in which it is administered. Medicaid is managed by the states and federal grants match state grants. Thus a state that is not willing to spend much on its poor will receive less money than a state that is willing to spend more, leaving people deprived at both state and federal level (Howard 179; Gilens 25). ${ }^{19}$ This state administration leads to very diverse Medicaid programs, with fifty separate state government plans which change often. As political scientist Laura Katz-Olson humorously puts it: "If you've seen one Medicaid program, you've seen one Medicaid program." (Katz-Olson 1) Differences exist at all levels: from the amount of funding and eligibility levels, to regulations and involved health industries (Jansson 248-9). This diversity also leads to staggering inequalities among beneficiaries between states. A person eligible for Medicaid in one state might not be so in the neighboring state. This creates a deep inequality between Medicare and Medicaid, leaving Medicaid exposed to restrictions due to state political ideology, making it a vulnerable program. The more conservative state governments is, the lower are the benefits people receive (Gilens 25). Most of the states with very low eligibility levels, in particular for parents (childless adults were excluded prior to the enactment of the Affordable Care Act), are in the South. 
In contrast, in Germany there is virtually no state variation, despite the great variety of health insurance companies (still 131 today). They have to operate within the same standardized framework and have to act in the same way for many aspects. Some critics deplore this lack of flexibility (Gerlinger and Burkhardt). Strong federal control also exists within the US system: Medicare is nationally administered and presents nearly no state variations.

Moreover, this two-tracked health care system has created two distinct constituencies of beneficiaries. One of the reasons of Medicare's longevity is the powerful AARP (American Association of Retired Persons). The AARP was among the fiercest and loudest opponents to Reagan's plan to cut Social Security and Medicare and largely managed to defeat his reform proposals (Brownlee and Graham 8-9). On the contrary, because of its less politically active constituency, the 1981 cuts in Medicaid under Reagan went largely unopposed, although the Reagan cuts included a $5 \%$ cap on the growth of the federal Medicaid share paid to the states, which made the program closer to a block grant program than an entitlement program (Slessarev 359). for a clear contrast with Europe. In most European countries, care for the elderly, or rather its associated costs, is a frequently mentioned problem. For example, in the UK, the elderly and their associated health care costs are perceived as an economic burden creating a crisis in the Welfare State. In fact, this constant framing of the elderly as a burden has led to the political alienation of a significant part of the retired population in the UK (Thane 139-40). This stands in sharp contrast with the American situation, where the AARP is a major player in health care policy and a dynamic political element.

Medicaid, on the other hand, has a rather politically inactive and diverse constituency. Constant reforms change the beneficiaries, which is further complicated by the varying eligibility levels of the different states, which makes it difficult to pin down the description of the average beneficiary. This makes mobilization on behalf of Medicaid more difficult (Howard 33-4; Katz-Olson 181; Jansson 291). ${ }^{20}$ An analysis by political scientist Andrea Louise Campbell shows that the mobilization of senior citizens is partly fuelled by the high stakes they have in Social Security and Medicare. She also highlights the link between low income and low education with low political participation (Campbell 30, 32), Medicaid beneficiaries being, by definition, low-income populations, explains why mobilization on behalf of Medicaid is less active.

In addition, the health care system as devised by the Johnson administration also laid the foundation for a racialization of the two programs. As mentioned earlier, the racial division of the American working class is one of the aspects that set the American health care and social policy history apart from that of other industrialized countries. It also can be said that racialization makes a unique tool for hampering the expansion of social policy and for cutting back existing programs.

Administration and funding created two programs that are perceived in distinct manners. Medicare is largely perceived as a "good" program whose beneficiaries have "earned" their benefits through lifelong contributions (notwithstanding the fact that the program pays out more than individuals have contributed and is partly funded through general tax revenues). Medicaid, on the other hand, has a less prestigious status. Katz-Olson explains that "Medicaid was initially considered Medicare's friendless stepchild, created in its shadow and catering to a politically powerless clientele." Her findings show that media coverage of Medicaid generally adopts a 
negative tone and describes a program that is out of control. Moreover, Medicaid is often part of partisan conflict regarding the administration of the program, and in particular over funding and benefit levels. This "has stirred up fears of fiscal disaster and images of unworthy clients taking advantage of taxpayer dollars." (Katz-Olson 1, 11) Despite Republican attacks on the program, it remains somewhat popular with the population. A 2011 Kaiser Family Foundation poll found that 47\% of Americans oppose spending cuts in Medicaid (although it was still the program getting the least popular support), and $39 \%$ of respondents declared that the program was important for them (Kaiser Family Foundation 2011).

Political scientist Martin Gilens has tried to bring clarity into an American paradox. Although people claim to be supportive of social policies and help for the needy, they oppose a wide range of measures, especially if those are labeled 'welfare.'(Katz-Olson 131; Gilens 30, 200) ${ }^{21}$ Gilens explains that this is due to a certain perception of the welfare recipient that has developed in the American public mind since the mid-1960s. This picture is one of an able-bodied black adult using welfare as a substitute for selfreliance. The perception is clearly one of the average welfare recipient as the lazy Black lacking work ethic. Hence the idea that most welfare recipients are undeserving and actually do not need the government's help, although Americans support government help for the deserving (Gilens 2-3, 36, 62-3, 67-8, 80, 187, 191). ${ }^{22}$ In short, social policies are racialized and opponents of social policies use race to argue for further cuts in the program. ${ }^{23}$

This image of undeserving minorities as parasitic beneficiaries builds on facts. Although in absolute numbers whites represent the majority of beneficiaries, the picture is slightly different when looking at it in proportion to the size of the communities. Minorities, particularly African-Americans and Latinos, are the poorest communities in the US..$^{24}$ This means they are the most likely to benefit from meanstested programs. ${ }^{25}$ This proportional overrepresentation of minorities allows for a racialized presentation of the program. The strong racialization of social policies, and health care in particular, might be the most distinctive element shaping the American system. 


\section{Medicaid population by race, 2009}

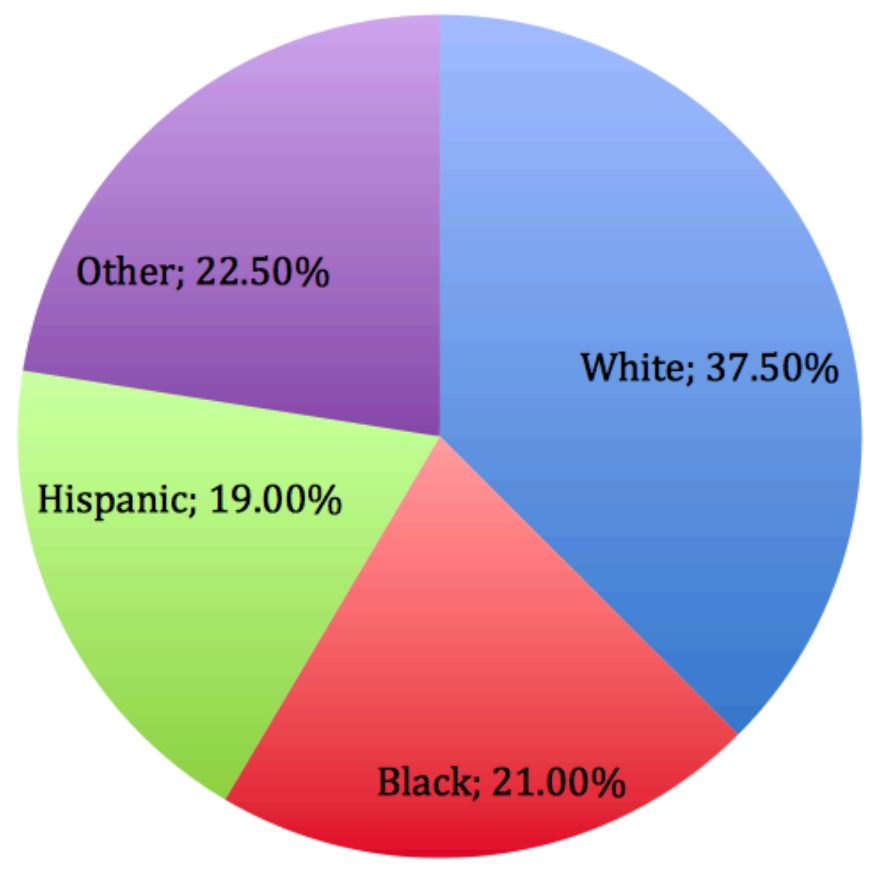

Adapted from CMS.gov. 2015 and US Census Bureau.

Blacks represent $21 \%$ of the Medicaid population, but they represent only $12 \%$ of the total population. Contrariwise, whites represent $37 \%$ of the Medicaid population, but $63 \%$ of the total population (see Figure 1). This allows for this presentation of Medicaid as a program for minorities.

41 The emergency plan devised by the Johnson administration created a particular situation for American health care, be it in its development, shape, or possibility for future reform. The fragmentation of American health care between a divided constituency and stakeholders' interests created a logjam for years making health care a recurrent reform project, as well as a recurrent political failure. Some argue that Conservatives saw the enactment of Medicaid and Medicare as a means to prevent a national health care system (Katz-Olson 28).

The lack of comprehensiveness of the Medicare-Medicaid system has often been pointed out as an American flaw. The majority of the American population relies on private insurance because the two programs only cover two distinct parts of the population: the elderly and the very poor. In 2009 , only $30.6 \%$ of the total population was covered by government health insurance (Medicare, Medicaid, or military health insurance). $64.5 \%$ of the population relied on private insurance, $56.1 \%$ of them benefited from employer insurance. Strong racial disparities apply here as well: $73.2 \%$ of the white population have private insurance, $62.7 \%$ of the white population have employer health insurance. This is the case for only $49.3 \%$ of the black population, where only $45.2 \%$ have employer insurance. The figures are even lower for Hispanics: only $40.7 \%$ of the Hispanic population has private insurance, and only $37.2 \%$ have employer insurance. The uninsured rates also greatly vary depending on the different populations. In 2009 , only $11.5 \%$ of the white population had no health insurance, but 
$20.3 \%$ of the black population lacked coverage, as did $31.6 \%$ of the Hispanic population (De Navas-Walt et al. 77-81). Thus the different racial populations of the US have very different stakes in health care reform and minorities are more in need of government responsiveness and health care reform because they rely less on the private market.

The situation in the US is not isolated. European states did not all immediately enact comprehensive and universal health care. France, for example, only progressively offered universal coverage, progressively including populations such as students, war widows, jobless persons, and interns between 1945 and 1978. Covered services were also extended, but in a piecemeal fashion and by population sectors (Elbaum 43-4.).

\section{Obama Facing A Minefield}

President Barack Obama made health care the major issue of his presidency and took a great risk doing so because he faced a political minefield. American health care history was characterized by nearly one century of failures to enact comprehensive health reform. The piecemeal system that emerged from successive waves of reform remains complex. This makes the system prone to misunderstandings and misrepresentations and it makes it difficult for the population to understand their interests in the system (Starr 10-1). To this must be added the fact that the health care constituency is divided along racial and class lines, making it more difficult to effectively address health inequalities.

Health care plays a central role in economic well-being (Wysong et al. 16, 79-80, 90). Minorities, and especially African-Americans, face particular health conditions that distinguish them from the rest of the population. ${ }^{26}$ Moreover, since the AfricanAmerican middle class is more fragile than the white one, they are more likely to face personal bankruptcy and loss of middle class status after serious illness. ${ }^{27}$

The will of the Obama administration to make health care more accessible for the poor and improve benefits was (and is) threatened by the negative image of Medicaid and its administration system.

The Clinton health reform debacle, spearheaded by Hillary clinton during her husband's presidency, showed that the creation of unity, both among reformers and the public, was paramount in achieving reform. Obama had a similar situation: the public apparently supported health care reform by a wide margin, even progressive health care reform. A New York Times poll in June 2009 found that $85 \%$ of respondents thought that the health care system needed to be changed. $72 \%$ of the respondents even supported "something like Medicare" for people under age 65, with only $20 \%$ of respondents opposing such a government-run system. The same poll found that even $50 \%$ of the respondents identifying as Republicans supported a public plan. This support should not be overestimated, however, as the same poll found that $77 \%$ of respondents were actually satisfied with the insurance plans they had (Sack and Connelly). A study by political scientists and statisticians Andrew Gelman, Daniel Lee, and Yair Ghitza found that, regarding public opinion, Obama faced a situation similar to Clinton's in 1993-4. They also caution that "Opinion is notoriously volatile on issues that are poorly defined in the public mind, and support of health care reform does not necessarily translate to support for any particular policy." (Gerlman et al. 2) What is more, their analysis shows that support varies greatly according to age and income categories. Not surprisingly, the higher the income, the higher the opposition to health 
care reform. More surprisingly, perhaps, is the fact that support for health care reform also dwindles with age and decreases for people over age 60 . The same age group was also less in favor of increased government spending on health care for the uninsured and on health care insurance in general (Gerlman et al. 7-8). In other words, a population that could have been viewed as an ally for health care reform, the elderly, who already benefit from a government-run plan, are among those less likely to support reform and an expansion of benefits like theirs to other parts of the population.

It has already been pointed out that the population categories most in need of health care reform, younger Americans in the lower income brackets, and especially minorities, are among the less politically active populations. Political scientist Larry M. Bartels pointed out that Congress tends to be more responsive to its richer voters and insisted on "the real limitations of public opinion as a basis for democratic policy making." (Bartels 6, 27-8) Thus, support for health care reform cannot predict the outcome of the reform proposal.

Gelman et al.'s analysis shows that, according to a survey in March 2010, support for Obama's reform proposal was only $46 \%$, while $48 \%$ opposed it. This support was sharply divided along partisan lines: $81 \%$ of Obama voters supported the proposal, while $90 \%$ of McCain voters opposed it (Gelman et al. 9). Obama was elected in 2008 with a majority of $52.9 \%$ of the popular vote (Roper Center 2014). This majority does not seem all that great when taking into account the sharp partisan division regarding the support for the health care reform proposal, especially when considering that the proposal managed 9 percentage points less support from Obama supporters than opposition from McCain supporters. What seemed like an overwhelming support for health care reform, with about $85 \%$ of people saying in 2009 that the system needed change, was reduced to $45 \%$ of support for the actual proposal (Jones). A 2012 analysis of public opinion regarding health care by political scientist Michael Tesler found that opinions concerning health care reform were racialized, as racial resentment played a stronger influence in the rejection of Obama's reform proposal than it did for Clinton's. In a short time span, attitudes changed between 2007 and 2009 and became more racialized once Obama had become the spokesperson for the health care reform proposal. Two elements stand out: support for the health care reform was divided along racial lines, with $83 \%$ of the black population supporting the Obama reform in 2009-2010, compared with $38 \%$ of whites. This racial polarization was less sharp for the Clinton reform proposal in 1993-4: 69\% of blacks supported the Clinton reform compared with $43 \%$ of whites. In September 2007, the most racially resentful respondents preferred private health insurance over government-run health insurance by $30 \%$ compared to the least racially resentful respondents. This increased to $60 \%$ by November 2009 , when Obama had become the spokesperson for the health care reform (Tesler 696, 698, 701). It appears then that the rejection of strong government involvement in health care, be it through a single payer system or in the form of the public option, is partly motivated by racial resentment.

50 This lack of support for a specific proposal is further complicated by the fact that the American system has effectively fragmented the health care constituents into different groups with different stakes: the poor needed a Medicaid expansion and improvement, whereas the elderly feared a loss of benefits, but they still needed a Medicare improvement, especially regarding the doughnut hole. ${ }^{28} 56 \%$ of the population was 
insured through their employers in 2009 (Proctor et al. 77), and unions had their privileges. Progressives made demands for government options for health care and some supported a single-payer system as in Canada.

51 This fragmented public opinion and health care constituency landscape meant that the apparently overwhelming support for health care could be easily fragmented and destabilized, just as was the case for Clinton in 1993-4. ${ }^{29}$

Moreover, the Obama administration had to deal with powerful health interest groups that had successfully opposed health care reform in the past. Among those are PhRMA, AHIP, AMA, AHA, small businesses, etc. ${ }^{30}$ The system had allowed the health care industries to enrich themselves, making them fierce opponents of reform. The system has accurately been described as a trap. Despite its obvious flaws, the public was just satisfied enough to be afraid of losing their advantages, making people wary of reform (Starr 2).

53 The passage of the ACA was a historic victory, although this can be easily overlooked. Health reform was declared dead several times, but Democrats had made a commitment and were determined. Nancy Pelosi, then speaker of the House and a key player in the health care reform said: "You go through the gate. If the gate's closed, you go over the fence. If the fence is too high, we'll pole-vault in. If that doesn't work, we'll parachute in. But we're going to get health care reform passed for the American people." (Qtd. in Kirsch 4) The resulting Act reflects Pelosi's words, because the reform was severely maimed by ideological and political assaults. Many concessions were made initially because the Obama administration wanted to create a bipartisan bill. Even though it rapidly became apparent that bipartisanship was more a matter of wishful thinking than reality, the Democratic majority in Congress, and especially in the Senate, was not strong enough and ideologically unified to achieve a truly progressive reform. Despite their non-participation in the reform debates, Republicans managed to impact the bill through two means: by unsettling public opinion and by later challenging the constitutionality of the ACA.

Although Obama's reform is rather centrist and was aimed at achieving bipartisan support, it still got him called a 'socialist'. Several Democratic members of Congress deplored the lack of Republican participation. Representative Robert E. Andrews (D-NJ) said: "I'm disappointed that the Republicans did not meaningfully participate in the process of writing this bill. They were given ample opportunity to do so." (Andrews) Representative Bart Gordon (D-TN) even regretted the attempts made at bipartisanship, given the almost total absence of success:

He [Obama] was, I'm afraid, a bit naïve at that time, thinking that there could be bipartisanship. He never received it, and still hasn't. So, and I think that he wasted some of his time in the presidency [...] it's a good instinct, I'm glad that he tried, but it was an effort that wasn't going to be successful. (Gordon)

Representative Earl Pomeroy (D-ND) has a somewhat harsher assessment of the situation, sparing neither of the two parties:

Democrats did not reach out meaningfully. We wanted to drag a Republican or two in, so we could claim it was bipartisan, but basically we did not reach out to the other side. Now, the other side also made it clear, right from the beginning, they weren't going to play, they almost double-dared us to do this, and there was much more interest in the political damage that they could inflict on the Party, than try to make the bill acceptable by any goals they had for health reform. (Pomeroy) 
Former Representative John Tierney (D-MA) said that Democrats encountered a total refusal from Republicans, who, even though they said that they wanted a different type of reform, made no recommendations. According to Tierney, Republicans only focused on the overreach of government (Tierney). In a 2016 article published in the Journal of the American Medical Association, Obama denounced Republicans' "hyperpartisanship" and he insisted on the fact that Republicans refused their own ideas, such as the individual mandate, but also others, when they were presented in the context of the health care reform proposed by the Obama administration (Obama 2016: 530). The refusal at bipartisan collaboration also highlights the strong political polarization around social policies, which often revolves around different conceptions about the role and scope of government. The accusations of a 'socialist' reform denote the rejection of a strong federal government and lead to the rhetorical use of the embedded notion of Big Government..$^{31}$ This is one of the reasons why the single-payer system, where the federal government manages all the health care costs, was never an option. Most congresspeople were against single payer out of electoral calculation. Former Representative Bart Gordon admitted that, in retrospect, a single payer system might have been a better approach, but that at that time it was "politically undoable." (Gordon) Former Representative Earl Pomeroy shared this assessment of the political situation: "It's impossible to achieve politically. You can only do that which you can pass and get the population to accept. And so moving from where we were to single payer was not going to happen." (Pomeroy) Although public opinion polls showed that a vast majority of Americans, about $70 \%$, criticized the existing health care system overall, only $20 \%$ were dissatisfied with their care and $40 \%$ were dissatisfied with costs at a personal level. Hence congresspeople feared electoral consequences if they supported a disruptive reform (Jacobs and Scocpol 89-90).

Even among progressives there was no majority in support of a single-payer system, as explained by Richard Kirsch, one of the activists of HCAN! (Kirsch 68). ${ }^{32}$ HCAN! feared that single payer would frighten public opinion and play into the hands of conservatives. Instead they chose to support the public option alternative (Kirsch 38, 80). ${ }^{33}$ Despite comparative studies that have shown the advantages and especially the cost-saving possibilities of the single payer system of their North American neighbors, strong anti-statist ideology prevented the mere discussion of a system akin to the Canadian one. Despite the lack of media coverage, single payer still has supporters, however, even in Congress. Yardly Pollas, senior legislative director for Representative Bobby Rush (D-IL), said that the congressman favored single payer as a better solution that would allow for fewer inequalities (Pollas 2016). Dan Riffle, health advisor to Representative John Conyers (D-MI), explained the congressman's long-standing interest in single payer as a means to achieve truly universal health coverage, dating back to the sixties when universal health care was advocated as part of the fight for civil rights. Rep. Conyers has been working toward introducing again a proposal for single payer (Riffle 2016).

Progressives had endorsed the public option as an alternative to single payer. Leaving the choice between private and government-run insurance was supposed to deflect attacks about a government takeover on health care. However, the public option very quickly became controversial. Among others, it was attacked by AHIP and Blue Shield Blue Cross, who are among the biggest insurers, because they feared the competition. Although Obama hesitantly supported the public option, it was eventually killed in the 
Senate (Kirsch 80-1, 112-3, 137, 161, 285; Jacobs and Skocpol 70-3, 80). At this stage of the debates, bipartisanship had long been abandoned and it was eventually a handful of conservative Democrats who defeated the public option in the Senate, ${ }^{34}$ as well as the proposal for a national health exchange (Klein; Mendelberg; Edsall and Edsall 12, 19, 71, 138; Brimes 66; Heclo 27-9; Kirsch 161, 289). The health exchanges would be administered at state level instead (Skocpol 99)..$^{35}$

Several congressmen highlighted the fact that the centrist move of the reform was, to a great extent, due to the ideological diversity on the Democratic side. Former Representative Robert E. Andrews summarized it as follows:

We had some Democrats who didn't vote for the bill, they had various reasons, some of them frankly thought that it didn't go far enough, they wanted a singlepayer health system like Canada has, others thought it went too far and they didn't want the taxes in the bill to help to pay for the extended coverage, other Democrats felt that it was a politically disadvantageous vote in their district and might cost them their election, and in fact it did cost some of them their election. (Andrews)

According to former Representative Bart Gordon, the conservative outreach of the reform was more to convince conservative Democrats than Republicans (Gordon). Even Representatives who voted for the ACA were dissatisfied with it. Representative John F. Tierney expressed his disappointment over the ACA saying that, by the end, it was clear that it was the "Senate bill or no bill at all," despite the fact that many would have liked to see a more progressive reform (Tierney). The threat of a Republican filibuster and the ensuing need of a solid 60-votes majority was enough to give the more moderate and conservative Democrats in the Senate disproportionate leverage. Political scientists Theda Skocpol and Lawrence Jacobs explained that the political exploitation of every negotiation between Democrats by "Republicans [who] cried "wolf" at each step, ma[de] normal legislative deal making visible to an increasingly anxious and bewildered public." (Jacobs and Skocpol 62-4) The impact of this highly publicized and protracted reform process must not be underestimated. Jacobs and Shapiro demonstrated that the focus on disagreement and disputes during a reform process contributed to unsettle the public and made public opinion turn against the clinton reform (Jacobs and Shapiro xvi, 65). During the Obama health care reform process, Senators from moderate or conservative states especially feared for their reelection prospects should they support a reform judged as too progressive. This was for example the case of Senator Blanche Lincoln of Arkansas (Jacobs and Skocpol 62).

61 In this sense, by destabilizing public opinion and making Democrats fear for their reelection prospects, the sharp Republican opposition managed to significantly impact the ACA and contributed to make it more centrist than many would have liked it to be, despite initial public opinion polls that appeared favorable to a major reform.

Former Representative John Tierney also pointed out that the death of Senator Kennedy had a huge impact on the bill. In his opinion, Kennedy's expertise, authority, and political savviness would have allowed for a much more progressive bill (Tierney). Conservative Democrats in the House threatened to withdraw their support if government funds could be used to cover abortions. On the other hand, pro-choice supporters threatened the reform, should abortion rights not be included (Kirsch 272-3, 275). ${ }^{36}$ Eventually the Stupak-Amendment was added, but even so, anti-abortion Democrats pushed President Obama into signing an additional executive order prohibiting the use of federal funds for abortions (Kantor 2010). 
63 It has already been mentioned that health care provider interests have been among the traditional opponents of health care reform in the US. They succeeded repeatedly in defeating reform efforts, which is why Obama made sure to invite them to the negotiations table, much to the resentment of progressive pressure groups (Kirsch 133, 148, 156). Longstanding opponents, such as the AMA and AHA, had been mollified through the promises of universal coverage and the ensuing prospects of new customers that would more than make up for the small income loss due to new regulations, such as caps on insurance premiums and out-of-pocket contributions. PhRMA was won over by special promises (that were in contradiction with campaign promises) that there would be no competition from generic drugs and no importation of cheaper drugs from other countries. In return, PhRMA invested in pro-reform advertisement (Jacobs and Skocpol 70-3). AHIP proved to be a tougher opponent. It was among those who managed to kill the public option, but enraged at the weakening of the penalties for non-compliance with the individual mandate (the obligation to contract health insurance), which was obtained by the Republicans. AHIP feared that they would only (sic) obtain $94 \%$ of the population as customers. Ironically, AHIP, with its long history of opposition to government action on health reform, actually complained about "too little government." ( Jacobs and Skocpol 73-4)

The remaining government intervention and regulation that the ACA provided for was challenged by Republicans. The 2012 Sebelius lawsuit, National Federation of Independent Business v. Sebelius, Secretary of Health and Human Services 648 F. 3d 1235, attacked the constitutionality of the individual mandate, which was eventually declared constitutional by the Supreme Court. The ironical feature of this conservative attack against the ACA is that, initially, the individual mandate was a conservative idea introduced in the Republican health reform proposal to oppose the 1993 Clinton plan (Jacobs and Shapiro 135). The individual mandate is also at the heart of the muchpraised Massachusetts health care system enacted by Republican Mitt Romney. When Democrats proposed the same idea, Republicans denounced it as "big government" and as an attack on personal liberty (Jacobs and Skocpol 91).

It has already been demonstrated that conservative opposition and outright attacks against too much government involvement took its toll on the health insurance system devised for the ACA: single payer was never really considered, the public option was abandoned. The ACA had thus to rely on several means to achieve universal coverage of the population. One of those means is the extension of Medicaid, the public health insurance program for the poor, to all people, including able-bodied adults without children, which were previously excluded from the program, and for incomes up to 133\% FPL. ${ }^{37}$ This extension was the other element, besides the individual mandate, that was challenged in the 2012 Sebelius lawsuit against the ACA. It was argued that the federal government had no right to penalize non-compliance with the new Medicaid extension with the loss of all federal Medicaid funds, depriving states of over $10 \%$ of their budget (National Federation of Independent Business... 2012). The Supreme Court ruled against the ACA and the Medicaid extension became optional, allowing once more the most conservative states to restrict Medicaid eligibility. ${ }^{38}$ This had a negative impact at two levels: on the universality of coverage and on the black population.

The universality of coverage was threatened by this, because the ACA relied on this extension to cover the poorest populations. First results have shown that the uninsured rates in the states without the Medicaid extension is still significantly higher than in 
the states having adopted the extension (Kaiser Family Foundation 2016b) (see Figures 2 and 3$)$.

Figure 2. Uninsured rates by states, in percent (2013)

Uninsured rates by states, in percent, 2013

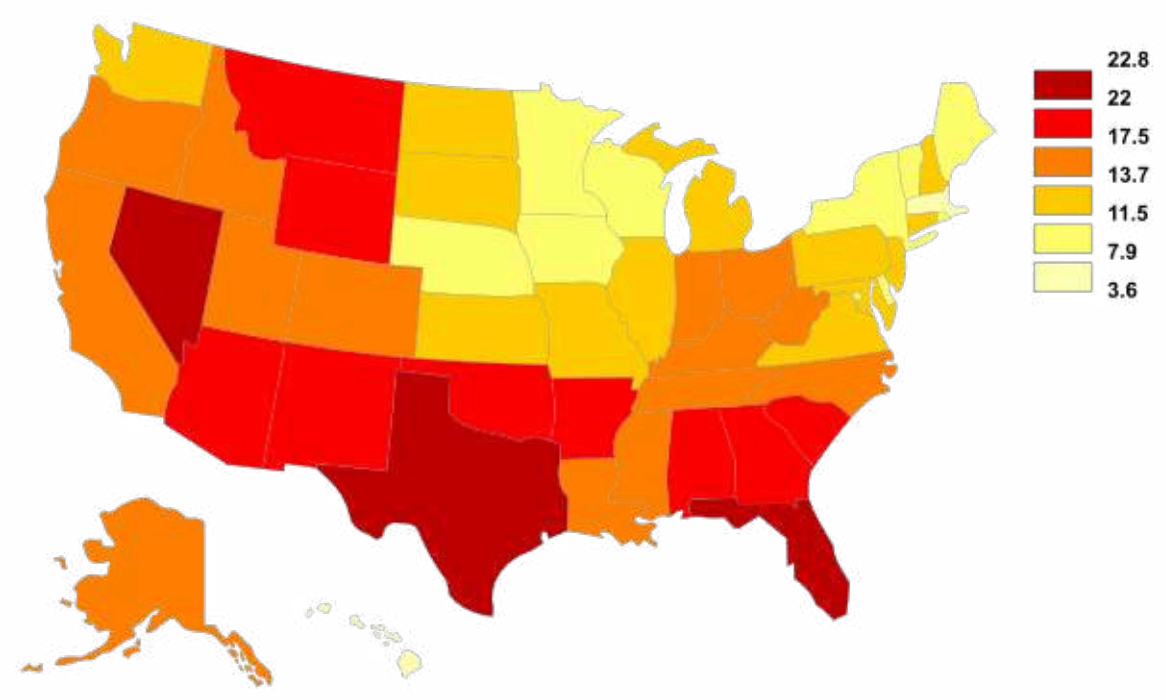

Adapted from the Kaiser Family Foundation.

Figure 3. Uninsured rates by states, in percent (2015)

Uninsured rates by state, in percent, 2015

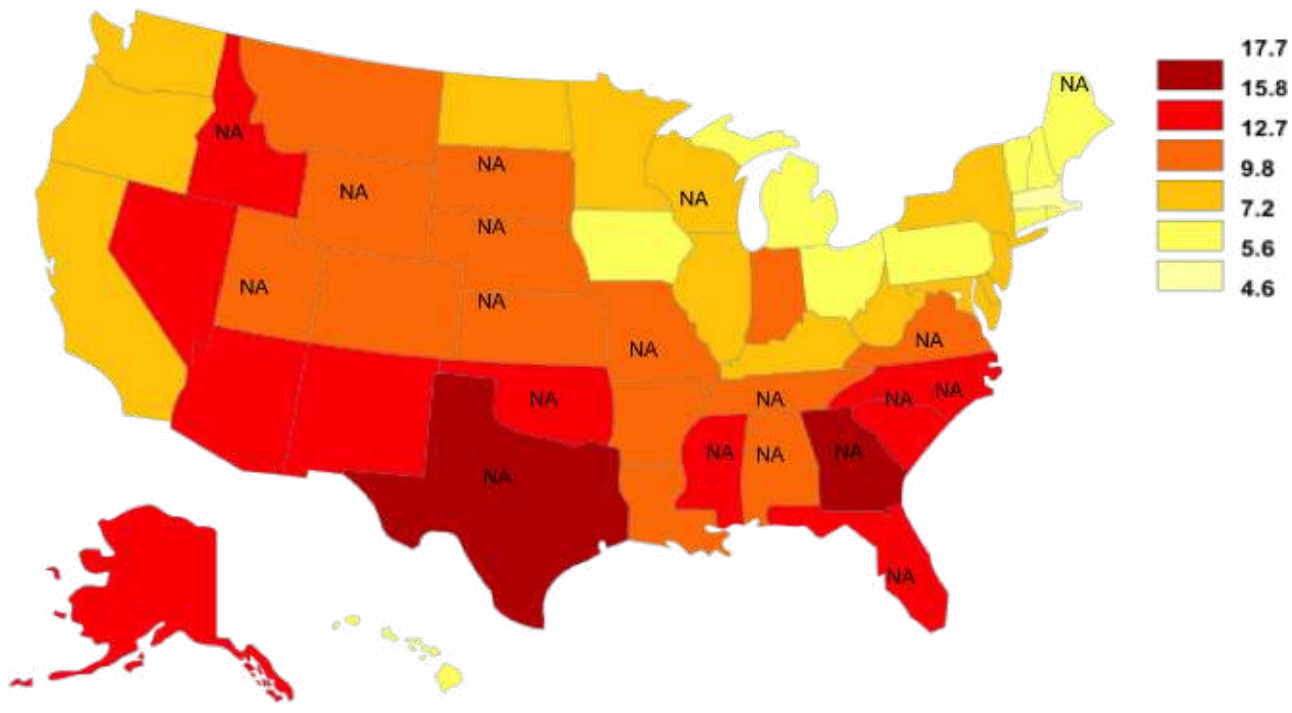

Adapted from the Kaiser Family Foundation. 
This had a clear impact on the poorest populations, and especially on the "working poor," i.e. people who work full time but do not manage to earn a sufficient living due to low wages and who have to forego health insurance. This decision had a disproportionately negative impact on blacks because Republican states, particularly in the South, did not implement the Medicaid extension, although it was fully financed at a federal level until 2017, and then slowly phased down to $90 \%$ of federal funding by 2020. As of January 2017, 19 states still have not adopted the Medicaid extension (Kaiser Family Foundation 2017c). These 19 states $^{39}$ concentrate $38.4 \%$ of the total American population, but $48.3 \%$ of the black population. Before Louisiana adopted the Medicaid extension in 2015 to be effective in 2016, the 20 states concentrated $51.8 \%$ of the total black population, compared with $39.9 \%$ of the total American population. The impact for Hispanics is not disproportionate in the 19 states, however, as $37.9 \%$ of the total Hispanic population lives in these states, which is slightly lower than the concentration rate of the total American population (see Figure 4). ${ }^{40}$

Figure 4. Population Concentration by Race and by State Medicaid Expansion Status, in percent, 2015

\section{9 non-Medicaid states}

\section{Medicaid states}

\section{Hispanic population Black population White population Total population}

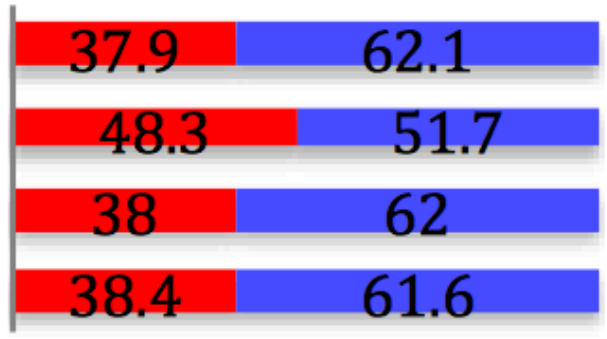

\begin{tabular}{|l|l|l|}
\hline & 19 non-Medicaid states & 31 Medicaid states \\
\hline Total population & 38.4 & 61.6 \\
\hline White population & 38 & 62 \\
\hline Black population & 48.3 & 51.7 \\
\hline Hispanic population & 37.9 & 62.1 \\
\hline
\end{tabular}


Figure 5. Medicaid eligibility levels for childless adults and density of the black population by state, in percent, 2014

Medicaid eligibility levels for childless adults and density of the black population by state, in percent, 2014

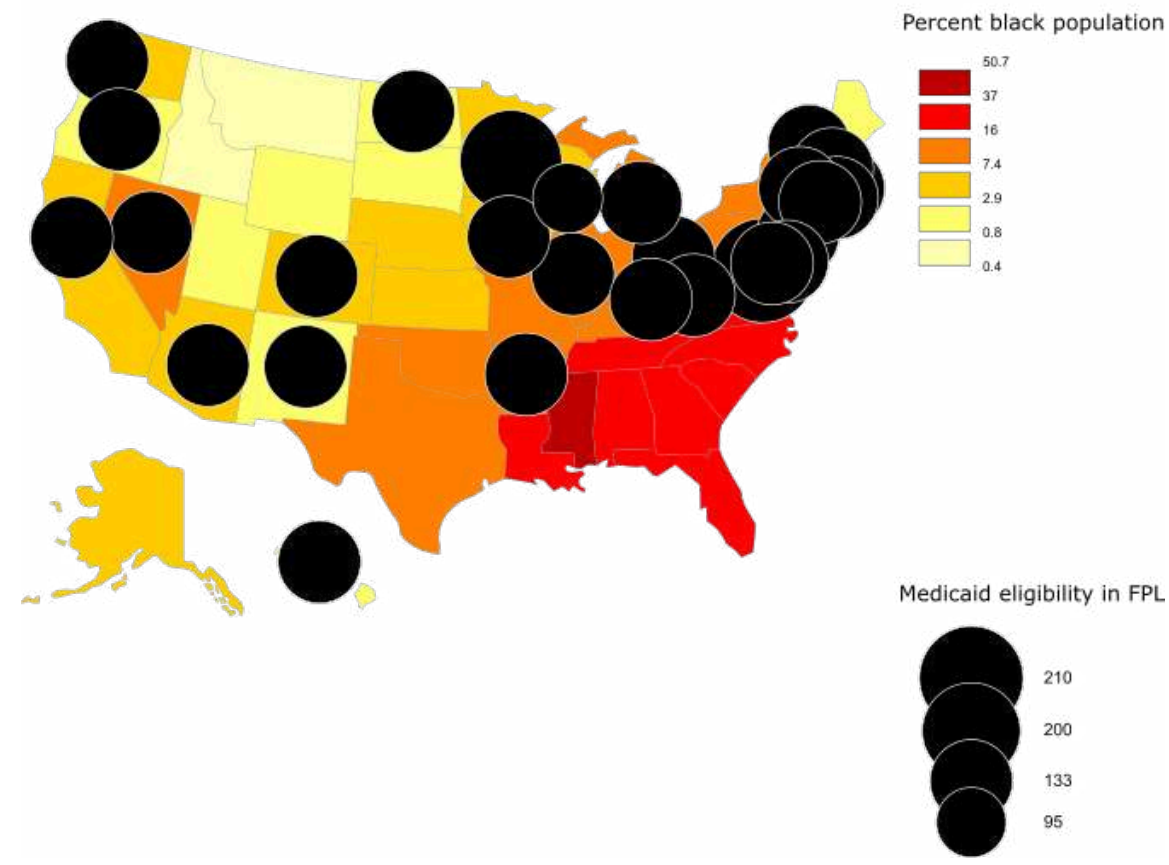

Data: Medicaid.gov, Census.gov.

It can be estimated that the black and the Hispanic populations suffer disproportionately from the non-extension of Medicaid in these states because they are among the poorest populations in the US (see Figure 5). In 2015, 21.7\% of the black population was in the lowest income brackets (up to an annual income of $\$ 15,000$ and thus eligible for the Medicaid extension) and $13.6 \%$ of the Hispanic population, compared with 9.3\% of the white population (Proctor et al. 25-6, 29). ${ }^{41}$

The more fragile status of Medicaid has been proved once again through the Sebelius decision and the ensuing refusal of a significant number of states to adopt the extension. It is understandable then that black Congressmen in particular, such as Representative Rush or Representative Conyers, favored single payer because such a system would not allow for this type of inequality in health care access (Pollard, Riffle). 42

Democratic congresspeople deplored the setback that this decision represented. Andrews said: "I respectfully think that the Supreme Court got that bit wrong. But because it's the Supreme Court, their decision is final, it's final for all of us and we got this." Pomeroy admitted that, at first, advocates may not have realized the heavy blow the law had taken in this Supreme Court decision: "We were so happy the whole law hadn't been tossed out, and it came very, very close to being tossed out, that, I think, there was maybe not enough attention paid about the terrible hit the law had taken." He then explains why Democrats did not immediately realize the extent of the damage: "We really didn't imagine that a... that Republican governors trying to extract the last bit of political advantage from this, what had become a very unpopular bill, would refuse a hundred percent funding from the federal government to cover their poor 
people. We really didn't imagine that level of venal and evil behavior in the name of politics." (Pomeroy)

71 Another divisive issue raised its head. The more liberal Democrats and some Hispanic congresspeople wanted undocumented immigrants to be able to purchase health coverage through the new health exchanges. More conservative and moderate Democrats were opposed to this. Republicans helped to fuel the debate. It was clear that an inclusion of illegal immigrants would expose the reform to even harsher attacks (Olivo; Skocpol and Jacobs 100; CNN 2009a; Kirsch 241-2, 342; Starr 240, 246). ${ }^{43}$

The planned premium cap on high-premium employer-sponsored health insurance plans, dubbed the 'Cadillac-Tax,' was one of the features of the reform designed to help make health care more affordable for the lower income population. But this tax was strongly opposed by the unions because their members were among the beneficiaries of those plans (Kirsch 111, 320; Starr 7, 75, 122, 258). ${ }^{44}$ Once again, the position of the unions, focused on their immediate special interest, proved damaging to the rest of the population (Jacobs and Skocpol 95). After bringing their support once the Cadillac Tax was delayed, unions resumed their opposition to the ACA. Some of their reproaches were based on legitimate concerns about the undesired effects of some ACA provisions. The ACA has one unintended effect on unions: it weakened their membership. Historically, many workers joined unions because of their health care bargaining capacities. The health exchanges and new regulations made this less appealing. Moreover, unions resented some of the redistributive aspects of the reform. Union members pay taxes that help subsidize lower-income families' health insurance, but their high-benefit high-cost plans are not subsidized (Roy). ${ }^{45}$

These examples show that the attitude of the unions has not significantly changed since they helped undermine FDR's attempts to introduce health care. Their position is a good example of the general zero-sum game fears raised by the health care reform, which pitch various interest groups against each other. This is also a manifestation of the racialization of social policies: when redistributive issues are tackled, the specter of racial group competition looms. These issues were also mentioned by Earl Pomeroy, former Representative of North Dakota, an at-large district with poverty issues. Regarding the need of addressing racial inequalities, he said, "I mean, of course, I don't want to go back to North Dakota, 95\% white population, saying, we have special provisions where if you're an ethnic, if you're a racial minority, you get to step to the front of the line. I mean, it wasn't going to pass." (Pomeroy) However, along with other Congressmen from states in similar situations, he managed to secure the Frontier Amendment, which increased Medicare reimbursement in North and South Dakota, as well as Montana, Wyoming, and Nevada. On the other hand, the better financing of Medicaid that Senator Ben Nelson from Nebraska initially obtained was harshly criticized by members of both parties and rapidly repealed (Lowrey), ${ }^{46}$ showing once again that it is more difficult to defend Medicaid than Medicare. Louisiana Senator Mary Landrieu, however, managed to carve out a Medicaid funding extension for her state in exchange of her support for the health care reform bill. The additional federal funding for Louisiana was restricted to that state under the provision that the increased funding only applied to "states recovering from a major disaster." (Fabia) Section 2006 of the ACA provides for additional Medicaid funding for all 50 states and the District of Columbia that have been declared by the president as a major disaster state during the preceding 7 fiscal years, thus applying to Louisiana which was hit by 
hurricane Katrina in 2005. Senator Landrieu managed to save her additional Medicaid funding despite Republican attacks, notably because she was backed by Republican Louisiana governor Bobby Jindal (Fabian). Senator Nelson's special deal could not be defended on similar grounds of heightened needs.

Intergroup competition is especially fierce in a context of perceived limited resources. Since the Gramm-Rudman-Hollings Act of 1985 and 1987, deficit control has become a central feature of social-policy making, thus creating a de facto situation of limited resources for all social policies. A Democratic bill that is not balanced has virtually no chance to pass. ${ }^{47}$ Obama made deficit control a central feature of his reform, along with cost control for patients, and worked closely with the $\mathrm{CBO} .{ }^{48}$ These unending debates about cost-control and deficit reduction made middle-class Americans and Medicare beneficiaries fear that they would lose benefits but have to pay to extend coverage to the poorer populations (Skocpol and Jacobs 97). ${ }^{49}$ This jeopardized their support for Obama's health reform project. The Obama administration was well aware of the critical role of the (white) middle class, especially after the Clinton disaster, especially given that, since the 1990s, affording health care coverage has increasingly become a middle-class problem (Wysong et al. 90).

As a result, the ACA strongly focuses on the middle class, for example by subsidizing health coverage for families with incomes up to 400\% FPL (ACA Title I sec. 1301, sec. 1311). This concerns a substantial part of the lower middle class, ${ }^{50}$ and addresses both political and economic needs. The 1970s backlash against social policies has shown that the middle class is less and less willing to support programs for the poor and minorities, especially since the middle class, and in particular the lower middle class, is doing increasingly poorly. Since the 1960s, the Democratic Party has increasingly been identified as the minority party. Many white working and lower middle class Democratic voters have been feeling less represented by their party and have turned towards the Republican Party. ${ }^{51}$ Moreover, since the 1970s the middle class status has been eroding, and health care insurance is among the problems that emerged for the middle class which has been facing sharply rising health care costs, which have started to become problematic since the 1990s. Any viable reform needed to address both issues: to help the lower middle class, while making this clear and obvious at the political level.

The strong racialization of general social policies explains why the resulting legislation uses virtually no race-specific language. ${ }^{52}$ Among the most conspicuous occurrences is Sec. 10334, "Minority Health," which re-affirms the Office for Minority Health. Among the re-authorized missions are "improving minority health and the quality of health care minorities receive, and eliminating racial and ethnic disparities." The more detailed missions include: "community outreach activities, language services, workforce cultural competence, and other areas as determined by the Secretary. “" ${ }^{53}$ The text is vague and addresses issues that are not particularly controversial. Such measures result in, for example, the availability of government websites in Spanish. This is hardly new and is only a form of compliance with existing legislation. Nonetheless, the ACA has been attacked by some as favoring racial minorities, calling it "affirmative action on steroids" in a poor attempt to appear witty, or an instance of "redistribution of health" (Velour; Jeffrey). Such attacks suggest that a more racespecific bill would never have passed in Congress. ${ }^{54}$ Although deep inequalities along race and class lines exist, at a political level, race-specific approaches are not seriously 
considered, as noted by Pomeroy who could not recall this issue being ever seriously discussed during health care reform meetings (Pomeroy). Tierney pointed out that ACA advocates tried as much as was possible to address the needs of minorities, but that the neutrality and universal focus of the bill was an absolute necessity (Tierney). These positions and assessments of the political situation are by no means unique. Obama was a long-time advocate of race-neutral/universal policies (Obama 2006: 247). Despite this openly advocated neutrality, he was harshly criticized by racial conservatives for doing too much, as shown in the examples above. But he was also harshly criticized for not considering more race-specific measures (Bonilla-Silva 262, 265). Democratic Maryland Representative Elijah E. Cummings criticized the president by saying that he could do more for African-Americans, but also voiced optimism that he would do so in a near future. The Congressional Black Caucus asked Obama to address the pressing needs of the African-American community (Stolberg; Condon and O'Sullivan; Brush). Despite these criticisms, the Congressional Black Caucus now officially supports the ACA and its website puts forward that the reform helps the African-American population (Congressional Black Caucus Foundation 2011) even if it is framed in race-neutral language.

Despite the existence of some superficial discussion about affirmative action-type policies in some European states and the passage of the Equality Act in 2010 in the UK (Boéton), ${ }^{55}$ the American racial situation is unique, particularly when it comes to the African-American population. The obvious differences between the US and Europe are, first, the fact that African-Americans are not immigrants or recently descended from immigrants, as is the case in Europe. Second, the issue of slavery and segregation make the American situation unique. Alleviating the effects of past discrimination was among the reasons for establishing race-specific policies like affirmative action. Despite the ongoing backlash at such policies, many people still defend them. Nowadays, the argument to defend racial policies includes the persisting inequalities between black and white communities (Anderson). ${ }^{56}$ To alleviate the effects of past discrimination, many academics and politicians advocate race-neutral but issue-specific policies, also called race-pragmatic policies. ${ }^{57}$ Different arguments are put forward. Many think that issue-specific policies have a deeper impact than symptom-treating policies like affirmative action. ${ }^{58}$ They also claim that universal policies have a better political survival chance and are key to build a broad coalition transcending race and class in order to achieve a reform-majority (West 98; Marable xxv, 199; Persons 1993b: 71; Sniderman and Carmines 153; Skocpol 251). Political feasibility is among the factors guiding this position, but this position is representative of the ideology of the post-civil rights black politics (Persons 1993a: 38). Obama is a good example of this 'new' turn in black politics.

Yet, political feasibility is just one aspect of the question. Supporters of race-specific policies have one major argument on their side: although problems like health care and education are universal and concern the whole of American society, those issues represent a far greater plight for the black population (De Navas-Walt et al. 26). ${ }^{59}$ Contrary to many European countries, the US does not consider racial statistics as discriminatory. ${ }^{60}$ Thus, everybody, including the government and the president, ${ }^{61}$ is well aware of the inequalities between populations and the dreadful situation of the black population. ${ }^{62}$ 

ability to pay, these community health centers are particularly important for minorities. The funding had already been almost doubled under president George W. Bush between 2002 and 2007 to almost $\$ 2$ billion (McMorrow and Zuckerman 992). ${ }^{65}$ The ACA expanded the funding further under sec. 10503. This funding was further increased by sec. 2303 of the Health Care and Education Reconciliation Act of 2010 (the second act that constitutes Obamacare) to a total of $\$ 11$ billion between 2011 and 2015, of which $\$ 1.5$ billion are dedicated to renovations and the construction of new centers. In 2015 the Department of Health and Human Services announced that under the ACA 700 new community health center sites had already been built, and 266 new centers were to be opened the same year (HHS 2015). This adds to the approximately 9,000 existing care delivery sites distributed among 1,202 community health centers that existed in 2013 (Shin et al.). It has already been mentioned that, because of the structural overlapping of race and class in the US and the ensuing concentration of the black population in the lowest income brackets, measures targeting the poorest populations disproportionally benefit blacks. Pomeroy insisted on the community health centers as one way to address the specific needs of the black population (Pomeroy).

81 Another way of dealing with life-threatening problems is by targeting specific pathologies. The major causes for death vary greatly between the black and white populations (CDC 2011: 137-8). ${ }^{66}$ For example, the ACA pays particular attention to HIV/ AIDS and diabetes, both having epidemic proportions in the black population (CDC. ${ }^{67}$ The ACA focuses on STD prevention (sec. 2953), in a wider program for assistance for pregnant and parenting teens that also includes education on birth control. Considering the spread of HIV/AIDS, high infant mortality rates, and high youth pregnancy rates (CDC 2014a) ${ }^{68}$ in the black population, those measures are sorely needed.

Andrews said that they tried to address some specific health issues that represent a wider problem for the American health system but particularly affect minority populations, such as diabetes, asthma, and high infant mortality rates (Mathews 4). ${ }^{69}$

83 The fact that even such measures as trying to rein in the spread of HIV/AIDS have been criticized by some racial conservatives as catering to the black community (Jeffrey 2009) bears witness to the racial tensions in the US, especially when redistributive policies are concerned.

84

Despite the progress that has been made thanks to the ACA, even Barack Obama admits that the system still must be improved. Obama points, among others, to the ongoing necessity of adjusting and balancing the insurance premiums, of further increasing 
insurer competition to bring down premium costs, of introducing a public plan at least in areas with insufficient marketplace competition, and of bringing down drug costs. Obama particularly insisted on the need to complete the Medicaid expansion (Obama 2016: 529-30).

\section{Conclusion}

The distinctive features of the American welfare state set it apart from other postindustrial countries. More specifically, the division of American society along racial lines has prevented the creation of truly comprehensive social programs, further entrenching social and economic inequalities. From its inception in 1965, the peculiar public health system stemming from racial divisions in the American working and middle class was unique in its lack of coverage and tremendous cost. The ACA has sought to address those shortcomings, such as difficulties to purchase health care insurance, or health inequalities between the different racial populations, while at the same time dealing with the social and political constraints of the United States today. The focus on the lower middle class and specific health issues allowed circumventing some of the opposition, especially against social policies targeted at minorities. However, it appears that the ACA is deeply shaped (or maimed) by those constraints and almost a hundred years of failed health care reforms.

\section{BIBLIOGRAPHY}

Anderson, Elizabeth. The Imperative of Integration. Princeton: Princeton UP, 2010.

Andrews, Robert E. Interview about Work on the Affordable Care Act. Interview by Lea Stephan. Phone, February 24, 2016.

Bai, Matt. "Is Obama the End of Black Politics?" The New York Times. August 10, 2008, sec. Magazine. http://www.nytimes.com/2008/08/10/magazine/10politics-t.html

Bartels, Larry M. Unequal Democracy: The Political Economy of the New Gilded Age. Princeton, New Jersey: Russell Sage Foundation/Princeton UP, 2008.

Bartlett, Bruce. "Medicare Part D: Republican Budget-Busting.” New York Times. November 19, 2013. http://economix.blogs.nytimes.com/2013/11/19/medicare-part-d-republican-budgetbusting/

Bekmezian, Hélène. "L’Assemblée vote la modulation des allocations familiales." Le Monde.fr, October 24, 2014, sec. Politique. http://www.lemonde.fr/politique/article/2014/10/24/1assemblee-vote-la-modulation-des-allocations-familiales_4512272_823448.html

Berkowitz, Edward D. America's Welfare State: From Roosevelt to Reagan. Baltimore: John Hopkins UP, 1991.

Blackbourn, David. The Long Nineteenth Century: A History of Germany, 1780-1918. New York: Oxford UP, 1998. 
Blank, Robert, and Viola Burau. "Setting Health Priorities Across Nations: More Convergence than Divergence." Journal of Public Health Policy 27: 3 (2006): 265-81. DOI: 10.1057/palgrave.jphp. 3200082

Boéton, Marie. “Discrimination Positive en France.” Études 398: 2 (2003): 175-84. https:// www.cairn.info/revue-etudes-2003-2-page-175.htm

Bonilla-Silva, Eduardo. Racism without Racists: Colorblind Racism and the Persistence of Racial Inequality in America. Lanham, MD: Rowman and Littlefield, 2014.

Boychuck, Gerard W. National Health Insurance in the United States and Canada: Race, Territory, and the Roots of Difference. Washington D.C.: Georgetown UP, 2008.

Brewer, Mark D., and Jeffrey M. Stonecash. Split: Class and Cultural Divides in American Politics. Washington, D.C.: CQ Press, 2007.

Brimes, Terri. "Reagan: The Soft-Sell Populist." In The Reagan Presidency: Pragmatic Conservatism and Its Legacies. Ed. W. Elliot Brownlee and Hugh Davis Graham. Lawrence, KS: U. of Kansas P., 2003.

Brownlee, W. Elliot, and Hugh Davis Graham, eds. The Reagan Presidency: Pragmatic Conservatism and Its Legacies. Lawrence, KS: U. of Kansas P., 2003.

Brush, Silla. "Black Caucus Tells Obama You've Done Too Little for African-Americans." The Hill. December 3, 2009. http://thehill.com/homenews/administration/70353-black-caucus-tellsobama-youve-done-too-little-for-african-americans-

Campbell, Andrea Louise. "Participatory Reactions to Policy Threats: Senior Citizens and the Defense of Social Security and Medicare." Political Behavior 25: 1 (March 1, 2003): 29-49. DOI: 10.1023/A:1022900327448

CDC. "Health, United States, 2010: With Special Features on Death and Dying." Hyattsville, MD: U.S. Department of Health and Human Services/Centers for Disease Control and Prevention/ National Center for Health Statistics, 2011.

CDC. “About Teen Pregnancy." Centers for Disease Control and Prevention, 2014a. http:// www.cdc.gov/teenpregnancy/aboutteenpreg.html

CDC. "HIV in the US at a Glance." Centers for Disease Control, 2014b. http://www.cdc.gov/hiv/ statistics/basics/ataglance.html

Census. "Selected Population Characteristics." 2011 American Community Survey Selection. Census Bureau/FactFinder, September 28, 2012.

Census. “Population Estimates, July 1, 2015, (V2015).” Accessed December 16, 2016. https:// www.census.gov/quickfacts/

CNN. “Rep. Wilson Shouts 'You Lie' to Obama during Speech." CNN Politics.com, September 10, 2009a. http://edition.cnn.com/2009/POLITICS/09/09/joe.wilson/.

CNN. "Senate Panel Votes Down Public Option for Health Care Bill." CNN.com, September 30, 2009b. http://edition.cnn.com/2009/POLITICS/09/29/senate.public.option/

Condon Jr., George E., and Jim O'Sullivan. “Has Obama Done Enough for Black Americans?" The Atlantic, April 5, 2013. https://www.theatlantic.com/politics/archive/2013/04/has-presidentobama-done-enough-for-black-americans/274699/

“Congressional Black Caucus Foundation." Government, January 14, 2011. http://www.cbcfinc.org 
Conley, Dalton. Being Black, Living in the Red: Race, Wealth, and Social Policy in America. 2nd ed. Berkeley: U. of California P., 2010.

Coste, Françoise. "Ronald Reagan and a New Partisan Identity: The Case of the Reagan Democrats." Paper presented at the conference on "American Identities: In Relation and Interaction," Université Toulouse II Le Mirail, June 2010.

Dorling, Danny. "Mapping the Thatcherite Legacy: The Human Geography of Social Inequalities in Britain since the 1970s." In The Legacy of Thatcherism: Assessing and Exploring Thatcherite Social and Economic Policies. Ed. Stephen Farral and Colin Hay. Oxford: Oxford UP/The British Academy, 2014.

DuBard, C. Annette, and Mark W. Massing. "Trends in Emergency Medicaid Expenditures for Recent and Undocumented Immigrants." JAMA 297: 10 (March 14, 2007): 1085-92. DOI: 10.1001/ jama.297.10.1085

Edsall, Thomas Byrne, and Mary D. Edsall. Chain Reaction: the Impact of Race, Rights, and Taxes on American Politics. New York: W.W. Norton, 1991.

Elbaum, Mireille. Économie politique de la protection sociale. $2^{\mathrm{d}}$ ed. Paris, France: Quadrige/Presses Universitaires de France, 2011.

“Equality Act 2010." Government Equality Office, May 8, 2015. https://www.gov.uk/government/ publications/2010-to-2015-government-policy-equality/2010-to-2015-government-policyequality

Evans, Robert G. "Extravagant Americans, Healthier Canadians: The Bottom Line in North American Health Care." In Canada and the United States: Differences That Count. Ed. David M. Thomas and Barbara Boyle Torrey. $3^{\text {rd }}$ ed. Ontario, Canada: Broadview Press, 2008.

Fabian, Jordan. “Obama Healthcare Plan Nixes Ben Nelson's ‘Cornhusker Kickback' Deal.” The Hill, February 22, 2010. http://thehill.com/blogs/blog-briefing-room/news/82621-obama-healthcareplan-nixes-ben-nelsons-cornhusker-kickback-deal

Fine, Michelle, and Lois Weis. The Unknown City: Lives of Poor and Working-Class Young Adults. Boston: Beacon Press, 1998.

Gelman, Andrew, Daniel Lee, and Yair Ghitza. "Public Opinion on Health Care Reform." The Forum (2010): 1-14. DOI: 10.2202/1540-8884.1355

Gerliner, Thomas, and Wolfram Burkhardt. "Bismarcks Erbe: Besonderheiten Und Prägende Merkmale Des Deutschen Gesundheitswesens," Bundeszentrale für Politische Bildung. March 1, 2012. http://www.bpb.de/politik/innenpolitik/gesundheitspolitik/72553/deutsche-besonderheiten.

Gilens, Martin. Why Americans Hate Welfare: Race, Media, and the Politics of Antipoverty Policy. Chicago: The U. of Chicago P., 1999.

Goodin, Robert E., ed. The Oxford Handbook of Political Science. New York: Oxford UP, 2011.

Gordon, Bart. Interview about Work on the Affordable Care Act. Interview by Lea Stephan, April 7, 2016.

Hacker, Jacob. The Divided Welfare State: The Battle over Public and Private Social Benefits in the United States. Cambridge (Mass.): Cambridge UP, 2002.

Heclo, Hugh. "Ronald Reagan and the American Public Philosophy." In The Reagan Presidency: Pragmatic Conservatism and Its Legacies. Eds. W. Elliot Brownlee and Hugh Davis Graham. Lawrence, KS: U. of Kansas P., 2003. 
HHS. "During National Health Center Week, HHS Announces an Additional \$169 Million in Affordable Care Act Funding to 266 Community Health Centers." Text. HHS.gov, August 11, 2015. https://wayback.archive-it.org/3926/20170127190419/https://www.hhs.gov/about/news/ 2015/08/11/hhs-announces-an-additional-169-million-in-affordable-care-act-funding-to-266community-health-centers.html

"H.J.RES.324 - Balanced Budget and Emergency Deficit Control Reaffirmation Act of 1987." Legislation, June 23, https://www.congress.gov/bill/100th-congress/house-joint-resolution/324

Howard, Christopher. The Welfare State Nobody Knows: Debunking Myths about US Social Policy. Princeton: Princeton UP, 2007.

Jacobs, Lawrence R., and Robert Y. Shapiro. Politicians Don't Pander: Political Manipulation and the Loss of Democratic Responsiveness. Chicago: U. of Chicago P., 2000.

Jacobs, Lawrence R., and Theda Skocpol. Health Care Reform and American Politics: What Everyone Needs to Know. New York: Oxford UP, 2012.

Jansson, Bruce S. The Reluctant Welfare State: American Social Welfare Policies-Past, Present, and Future. Belmont, CA: Thomson Brooks/Cole, 2005.

Jeffrey, Terence. “Obama Wants to Redistribute Health, Too.” Creator.com., 2009. http:// legacy.creators.com/opinion/terence-jeffrey/obama-wants-to-redistribute-health-too.html Jones, Jeffrey M. “In U.S., 45\% Favor, 48\% Oppose Obama Healthcare Plan.” Gallup, March 9, 2010. http://www.gallup.com/poll/126521/Favor-Oppose-Obama-Healthcare-Plan.aspx.

Kaiser Family Foundation. "Medicare Advantage.” May 11, 2016a. http://kff.org/medicare/factsheet/medicare-advantage/.

Kaiser Family Foundation. "Key Facts about the Uninsured Population.” September 29, 2016b. http://kff.org/uninsured/fact-sheet/key-facts-about-the-uninsured-population/.

Kaiser Family Foundation. "Pulling It Together: A Public Opinion Surprise.” April 4, 2011. http:// kff.org/health-reform/perspective/pulling-it-together-a-public-opinion-surprise/.

Kaiser Family Foundation. "Current Status of State Medicaid Expansion Decisions," January 1, 2017c. http://kff.org/health-reform/slide/current-status-of-the-medicaid-expansion-decision/.

Kantor, Jodi. “Abortion Foe Defies Party on Health Care Bill,“ New York Times, January 6, 2010. http:// www.nytimes.com/2010/01/07/us/politics/07stupak.html

Katz, Michael B. The Price of Citizenship: Redefining the American Welfare State. New York: Owl book, 2002.

Kirsch, Richard. Fighting for Our Health: The Epic Battle to Make Health Care a Right in the United States. Albany, N.Y.: The Rockefeller Institute Press, 2011.

Lacy, Karyn R. Blue-Chip Black: Race, Class, and Status in the New Black Middle Class. Berkeley: U. of California P., 2007.

Comité d'histoire de la Sécurité sociale (CHSS). "La Sécurité Sociale : Des origines à nos jours." Exposition Commémorative de la création de la Sécurité Sociale. Paris: La documentation française, 2005.

Lowrey, Annie. "What If Senators Represented People by Income or Race, Not by State?" The Washington Post, February 7, 2010, sec. Opinions. http://www.washingtonpost.com/wp-dyn/ content/article/2010/02/05/AR2010020501446.html. 
MacDorman, Marian, T. J. Mathews, Ashna D. Mohangoo, and Jennifer Zeitlin. "International Comparison of Infant Mortality Rates and Related Factors: United States and Europe, 2010." National Vital Statistics Report, September 25, 2014.

Marable, Manning. Beyond Black and White: From Civil Rights to Barack Obama. 2nd ed. New York: Verso, 2009.

Mathews, T. J., Marian MacDorman, and Marie E. Thoma. "Infant Mortality Statistics From the 2013 Period Linked Birth/Infant Death Data Set.” National Vital Statistics Report, 2015.

McMorrow, Stacey, and Stephen Zuckerman. "Expanding Federal Funding to Community Health Centers Slows Decline in Access for Low-Income Adults." Health Services Research 49:3 (June 2014): 992-1010. DOI: 10.1111/1475-6773.12141

medicaid.gov. "Medicaid and CHIP Eligibility Levels.” Accessed December 19, 2016. https:// www.medicaid.gov/medicaid/program-information/medicaid-and-chip-eligibility-levels/ index.html.

Medicare.gov. "Your Medicare Coverage." Government agency, n.d. https://www.medicare.gov/ coverage/hospital-care-inpatient.html.

Mendelberg, Tali. The Race Card: Campaign Strategy, Implicit Messages, and the Norm of Equality. Princeton: Princeton UP, 2001.

National Federation of Independent Business et Al. V. Sebelius, Secretary of Health and Human Services, et Al. 648 F. 3d 1235, 2012. http://www.law.cornell.edu/supremecourt/text/

11-393\#writing-11-393_SYLLABUS.

Navas-Walt, Carmen De, Bernadette D. Proctor, and Jessica C. Smith. "Income, Poverty, and Health Insurance Coverage in the United States: 2010." Household Economic Studies. Current Population Reports/Consumer Income. Census Bureau/U.S. Department of Commerce, September 2011.

Noble, Charles. Welfare as We Knew It: a Political History of the American Welfare State. New York: Oxford UP, 1997.

Obama, Barack. The Audacity of Hope: Thoughts on Reclaiming the American Dream. Edinburgh: Canongate, 2006.

Obama, Barack. "United States Health Care Reform: Progress to Date and Next Steps." Journal of the American Medical Association 316: 5 (August 2, 2016): 525-32. DOI: 10.1001/jama.2016.9797

Oliver, Melvin L., and Thomas M. Shapiro. Black Wealth/ White Wealth: A New Perspective on Racial Inequality. New York: Routledge, 1995.

Oliver, Thomas R., Philip R. Lee, and Helene L. Lipton. "A Political History of Medicare and Prescription Drug Coverage.” The Milbank Quarterly 82: 2 (June 2004): 283-354. DOI: 10.1111/j. 0887-378X.2004.00311.x

Olivo, Antonio. "Debate Heats up on Healthcare for Illegal Immigrants." Los Angeles Times. August 11, 2009. http://articles.latimes.com/print/2009/aug/11/nation/na-health-immig11

Patel, Kant, and Mark E. Rushefsky. Health Care Politics and Policy in America. 3rd ed. Armonk, NY: M.E. Sharpe, 2006.

Persons, Georgia A. "Black Mayoralties and the New Black Politics: From Insurgency to Racial Reconciliation.” In Dilemmas of Black Politics: Issues of Leadership and Strategy. Ed. Georgia A. Persons.New York: Harper Collins, 1993a. 38-65. 
Persons, Georgia A. Dilemmas of Black Politics: Issues of Leadership and Strategy. New York: Harper Collins, 1993b.

Pollas, Yardly. Interview with Lea Stephan. Washington, D.C., April 12, 2016.

Pomeroy, Earl. Interview about Work on the ACA. Interview by Lea Stephan at Alston and Bird lawfirm, Washington, DC, April 5, 2016.

“Population Estimates, July 1, 2015, (V2015).” Accessed December 16, 2016. https:// www.census.gov/quickfacts/table/PST045216/01,00

Powell, Martin. “Analyzing the 'New' British National Health Service.” International Journal of Health Planning and Management 15 (2000): 89-101. DOI: 10.1002/1099-1751(200004/06)15:2<89::AIDHPM $580>3.0 . C O ; 2-\mathrm{A}$

Truman, Harry. “President Truman's Proposed Health Program. November 19, 1945” Harry S. Truman Presidential Library. http://www.trumanlibrary.org/anniversaries/healthprogram.htm .

Proctor, Bernadette D., Jessica L. Semega, and Melissa A. Kollar. "Income and Poverty in the United States: 2015.” Current Population Reports. Census Bureau/U.S. Department of Commerce, September 2016.

Riffle, Dan. Interview with Lea Stephan. Washington, D.C., April 7, 2016.

Roper Center. “Popular Votes 1940-2012." Roper Center, Cornell University, November 26, 2014. http://ropercenter.cornell.edu/polls/us-elections/popular-vote/.

Roy, Avik. “Labor Unions: Obamacare Will 'Shatter' Our Health Benefits, Cause 'Nightmare Scenarios.” Forbes. April 21, 2015. http://www.forbes.com/sites/theapothecary/2013/07/15/ labor-leaders-obamacare-will-shatter-their-health-benefits-cause-nightmare-scenarios/ Sack, Kevin, and Marjorie Connelly. "In Poll, Wide Support for Government-Run Health." New York Times. June 20, 2009. http://www.nytimes.com/2009/06/21/health/policy/21poll.html Schiff, Gordon, and Claudia Fegan. "Commentary: Community Health Centers and the Underserved: Eliminating Disparities or Increasing Despair." Journal of Public Health Policy 24:3/4 (2003): 307-11. DOI: 10.2307/3343377

“Selected Economic Trends.” U.S. Census Bureau, 2006-2010 American Community Survey, n.d. Shapiro, Thomas, Tatjana Meschede, and Sam Osoro. "The Roots of the Widening Racial Wealth Gap: Explaining the Black-White Economic Divide." Research and Policy Brief. Waltham, MA: Brandeis University/Institute on Assets and Social Policy, February 2013.

Shin, Peter, Zoe Barber, Sara Rosenbaum, and Julia Paradise. "Community Health Centers: A 2013 Profile and Prespects as ACA Implementation Proceeds." kff.org, March 17, 2015. http://kff.org/ report-section/community-health-centers-a-2013-profile-and-prospects-as-aca-implementationproceeds-issue-brief/

Skocpol, Theda. Social Policy in the United States: Future Possibilities in Historical Perspective. Princeton: Princeton UP, 1995.

Slessarev, Helene. "Racial Tensions and Institutional Support: Social Programs during a Period of Retrenchment." In The Politics of Social Policies in the United States. Eds. Margaret Weir, Ann Shola Orloff, and Theda Skocpol. Princeton: Princeton UP, 1988, 357-80.

Sniderman, Paul M., and Edward G. Carmines. Reaching Beyond Race. Cambridge: Harvard UP, 1997. Soss, Joe, Richard C. Fording, and Sanford F. Schram. Disciplining the Poor: Neoliberal Paternalism and the Persistent Power of Race. Chicago: U. of Chicago P., 2011. 
Starr, Paul. Remedy and Reaction: The Peculiar American Struggle over Health Care Reform. New Haven: Yale UP, 2011.

"State and Legislative Partisan Composition." National Council of State Legislatures, September 7, 2016. http://www.ncsl.org/Portals/1/Documents/Elections/Legis_Control_2016_Sept7.pdf

Stolberg, Sheryl Gay. "For Obama, Nuance on Race Invites Questions." New York Times. February 9 , 2010, sec. U.S. / Politics. http://www.nytimes.com/2010/02/09/us/politics/09race.html

Taylor, Paul, Rakesh Kochar, Richard Fry, Gabriel Velasco, and Seth Motel. "Twenty-to-One:

Welath Gaps Rise to Record Highs Between Whites, Blacks, and Hispanics." Social and Demographic Trends. Washington D.C.: Pew Research Center, July 26, 2011.

Tesler, Michael. "The Spillover of Racialization into Health Care: How President Obama Polarized Public Opinion by Racial Attitudes and Race." American Journal of Political Science 56.3 (2012):

690-704. DOI: 10.1111/j.1540-5907.2011.00577.x

Tierney, John. Interview about Work on the Affordable Care Act. Interview by Lea Stephan. Phone, December 10, 2015.

U. S. Social Security Administration, Office of Retirement and Disability Policy. "Annual Statistical Supplement, 2011 - Medicare Program Description and Legislative History," April 20, 2015. http://www.ssa.gov/policy/docs/statcomps/supplement/2011/medicare.html

Valtriani, Patrick. Les Politiques sociales en France. $2^{\text {nd }}$ ed. Paris, France: Hachette supérieur, 2011.

Velour, Crush T. "Reparations by Way of Health Care Reform.” The Free Republic. July 28, 2009. http://www.freerepublic.com/focus/news/2302691/posts

Walker, Carol. “'Don't Cut Down All the Poppies': Thatcherism and the Strategy of Inequality.” In The Legacy of Thatcherism: Assessing and Exploring Thatcherite Social and Economic Policies. Ed. Stephen Farral and Colin Hay. Oxford: Oxford UP/The British Academy, 2014.

West, Cornel. Race Matters. 3rd ed. New York: Vintage Books, 1993.

Wilson, William Julius. The Declining Significance of Race: Blacks and Changing American Institutions. $3^{\text {rd }}$ ed. Chicago: U. of Chicago P., 2012.

Woodward, C. Vann, ed. The Comparative Approach to American History. New York: Oxford UP, 1997. Wysong, Earl, Robert Perrucci, and David Wright. New Class Society: Goodbye American Dream? $4^{\text {th }}$ ed. Lanham, MD: Rowman and Littlefield, 2014.

\section{NOTES}

1. Evans stresses the fact that the major differences in Western world health care systems can be found in the financing. The rest of the features are remarkably similar. In this sense, the US is truly exceptional. In most countries, the funding depends on the type of benefit (hospital, physician, dentistry, and ophthalmology are the main categories). In the US, however, it depends on the beneficiary. Moreover, the US is exceptional in its cost-to-care ratio: it shows [It is too early to say if the ACA manages to solve the problem.] the greatest gap between the overall costs of health care and the proportion of the population that receives care. A similar argument is made by political scientist Jacob Hacker (2002). Moreover, Hacker argues that the American welfare state is not reduced as many say, based on its high expenditure, and that a significant part is to be found in the private sector. 
2. By excluding domestic and casual workers, the program would have excluded most minorities. The same scheme was later used for Social Security. Domestic and agricultural workers were finally made eligible in the 1950 Social Security reform.

3. Social policies were the carrot. The stick was anti-socialist laws.

4. In France, during the late $19^{\text {th }}$ century, only minor laws regarding public assistance to the indigent were enacted. In 1898 insurance for miners was enacted, as well as a law regarding accidents in the workplace. Only in 1928-30 was a social insurance enacted, funded partly by employers and partly by employees. Family assistance was developed in 1932, spurred by the effects of the Great Depression.

5. Since 1967 it was about 70\% (depending on the type of care and health product), the remaining part being covered by private insurances that are not mandatory and can be paid as out-ofpocket expenses. For example, in 2010, 9.4\% of all medical expenses (care and medical material) were paid as out-of-pocket expenses and $3.6 \%$ of expenses were optional insurances, not including the expenses for mutuelles, the private, non-mandatory additional health insurances.

6. Both Roosevelt and Johnson benefited from a window of opportunity, meaning that the political and economic context was in their favor. FDR used the Great Depression and the plight of millions of homeless and jobless people to create the basis of the Welfare State. Kennedy benefited from quite an opposite context: the affluence of the 1950s and 1960s in the post-World War II economic boom created a context of increased willingness to share resources. However, it was Johnson who managed to use this window of opportunity.

7. Agrarian interests, however, opposed social policies. This constitutes a parallel with the US, where the more agrarian South opposed Medicaid expansion.

8. In France, health care was initially promoted as a system based on unity, universalism, and uniformity, as recommended by the British Beveridge report of 1942. The British National Health Service enacted these principles. The French sécurité sociale, however, ended up being based more on the continuity of existing legislation with a scattered system of public and private insurance and many different "régimes" depending on the professions. Thus the French health insurance system replicates the stratification of society (Elbaum 41, 43).

9. At the beginning of health insurance in Germany, there were 17,511 insurance companies. Indeed, each profession in each state had a specific insurance company with automatic and compulsory affiliation.

10. Feagin especially develops the idea that racialized class relations (and hence divisions) are a well-established American political tradition, dating back to the beginning of the colonies to establish elite privileges. Subsequently the racialized class division has been used (and still is today) as an efficient means to hamper the development of social policies and redistributive measures, thus maintaining elite privileges for a small number of white males.

11. This dividing rhetoric is enhanced by "H.J.RES.324" (1987) which is a central tool in hampering the development of social policies. This act requires that every new reform must be balanced and not increase the deficit. Reagan largely used this as a strategy for cutting social programs. Reagan dramatically increased military spending and thus the deficit. Later on, he argued that social policies were causing the deficit and moved to cut spending. Moreover, he presented social policies as a zero-sum game where white middle class families would pay taxes to finance useless social programs for undeserving minorities who lived an immoral and lazy life. This strategy is best explained by Edsall and Edsall (1991). The phenomenon of the ReaganDemocrats is also explained by Françoise Coste (2010). The role played by values in this phenomenon is analyzed by Brewer and Stonecash (2007).

12. A separatist movement had started in 1963 in the province of Quebec which resented everything that resembled Canadian nation-building. Federal health care was seen as a threat to the independence of the provinces. 
13. Today the situation is slightly different. The most notable exception is Washington D.C. with $216 \%$ of Federal Poverty Level (FPL) for the eligibility for Medicaid benefits. In Alabama it was as low as 13\% FPL, for parents in 2014 (childless adults are not eligible). FPL in 2014 was $\$ 11,670$ (Medicaid.gov 2016).

14. Especially California and New York expanded their programs. New York had included their blue-collar citizens, thus covering up to $40 \%$ of the population by Medicaid. New federal regulations limited eligibility to $133 \%$ FPL in all states by 1970 .

15. Block grants were introduced by president George H. W. Bush in 1990, leading to further cuts in benefits and eligibility.

16. The other Republican dream come true under the Clinton administration was the reform of Aid for Families with Dependent Children (AFDC) that was transformed into the way more conservative Temporary Assistance for Needy Families (TANF) through the Personal Responsibility and Work Opportunity Act of 1996. AFDC was a means-tested program, but there was no lifetime limit. With TANF, beneficiaries are entitled to only 5 years of assistance over their whole life. In France, in 2014, the Allocations Familiales, a universal program of cash benefits for children has become means tested. The benefits are regressive depending on income. See Bekmezian (2014). The interesting comparative point is that the program cut was made by a leftist government, just as the AFDC reform was made by the Democratic Clinton government, although the French reform is less harsh by far than the American reform. However, the ideological approach of the two reforms were widely different. The French reform aimed the wealthiest families, whereas the American reform touched low-income single mothers.

17. George W. Bush saw himself as Reagan's political heir.

18. For example, the Medicare coverage of hospital stays in 2016 included the following financial participation: a $\$ 1,288$ deductible for each hospital stay benefit period (minimum of 2 days). The first 60 days of hospitalization in a benefit period are without coinsurance. Days 60 to 90 of the benefit period require a coinsurance of $\$ 322$ per day for each benefit period. Days 91 and beyond are called "lifetime reserve days" and a patient can benefit of a maximum of 60 over a lifetime. Otherwise patients have to cover all cost. Each of the lifetime reserve days requires a coinsurance of $\$ 644$. To begin a new benefit period, the patient must have been out of hospital for at least 60 days.

19. It has been shown that conservative states have considerably lower welfare benefits than liberal states. Moreover, states with high minority populations tend to have lower benefits. The same trend has been observed for TANF (Temporary Assistance for Needy Families) benefits.

20. The beneficiaries of Medicaid are the poor elderly, the disabled below 75\% FPL, pregnant women and children under age 6 up to 133\% FPL. Medicaid also includes children under age 18 with eligibility up to $100 \%$ FPL. Poor able-bodied adults have been added, but this remains optional. Parents/caretakers of low-income families qualify since 1996 if their income is below 41\% FPL. Before the TANF reform, all persons on AFDC (Aid to Families with Dependent Children, reformed into TANF) were automatically eligible for Medicaid. Moreover, states can chose to provide Medicaid benefits for the medically needy. CHIP (Children's Health Insurance Program) provides additional coverage for children until age 18 (20 in some cases). Initially it was president Carter's welfare reform in 1977 that achieved a better enforcement of the coverage of children and the addition of pregnant women. The next expansion of children's coverage was in 1997 with the creation of SCHIP, later called CHIP.

21. However, it must be specified that the American public opinion does not seem to be quite sure of what 'welfare' actually means. When a question uses the term 'welfare' or if an issue is framed as being 'welfare', then people strongly oppose it. However, when asked about specific measures, such as support for mothers or medical help, or even just help for the needy, Americans become very charitable and supportive. It must be added, however, that their support is generally much stronger for programs that promote self-reliance or aim at future self-reliance 
such as job-training or education programs. Their support is weaker for in-kind programs (medical care and public housing, for example), and is weakest for cash-assistance or assimilated, such as food stamps.

22. Gilens stressed the fact that mothers with children are perceived as deserving. However, this must be nuanced because one of the programs that suffered the strongest cuts was AFDC. It was reformed into TANF by the Clinton administration in 1996, ending its entitlement status and making it a time-limited program (Fine and Weiss xiii, 3-4).

23. Space does not allow here for a detailed discussion of the racialized discourse and rhetoric around social policies.

24. The economic status can be determined through many different ways, not only income. In 2009 , the white-to-black wealth ratio was 19 , the white-to-Hispanic ration was 15 . The median net worth of households in 2009 was $\$ 113,149$ for whites, $\$ 6,325$ for Hispanics, and $\$ 5,677$ for blacks. See Taylor et al. (2011). In 2010, the Federal Poverty Level was at $\$ 10,830$ for one person. $4.5 \%$ of the total population, $3.3 \%$ of the white population, and $10.3 \%$ of the black population were living in poverty ("Selected Economic Trends").

25. The space does not allow for a detailed explanation of the origins of these racial inequalities. Suffice it to say that these inequalities are caused by past and present racial discrimination, which is why it is necessary to compensate for structural inequalities with redistributive policies. 26. In 2009, many people lacked health insurance: $16.1 \%$ of the total population, $11.5 \%$ of the white population, $20.3 \%$ of the black population, and $31.6 \%$ of the Hispanic population (De NavasWalt et al. 26). Moreover, there are marked differences in the morbidity rates. In 2007, the death rates of all causes were: total population 760.2 (per 100,000), whites 749.4, blacks 958, Hispanics 546.1. Regarding some specific pathologies, the differences are striking. The differences for diabetes mellitus were: total population 22.5, whites 20.5, blacks 42.8, Hispanics 28.9. For HIV/ AIDS: total population 3.7, whites 1.9, blacks 17.3, Hispanics 4.1 (CDC 137-9). Regarding HIV/AIDS, not only are the morbidity rates frightening, but so is the number of people living with the disease: in 2014 blacks represent $44 \%$ of the people living with HIV/AIDS (but they represent only $12 \%$ of the total population) (CDC 2014b).

27. Melvin L. Oliver and Thomas M. Shapiro (1995) make a detailed demonstration of the greater fragility of the black middle class compared to the white middle class. See also Taylor et al. (2013); Dalton Conley (2010). For a detailed analysis of the specificities of the black middle class, especially regarding social interaction, see Karyn R. Lacy (2007).

28. The doughnut hole has not yet been eliminated. Currently (2016) it is between $\$ 3,310$ prescription drug fees before catastrophic coverage kicks in at $\$ 4,850$. In the doughnut hole, people have to pay $45 \%$ out-of-pocket for brand drugs and $42 \%$ for generic drugs. However, $95 \%$ of the costs are counted as out-of-pocket contributions to allow to reach the catastrophic coverage faster. Persons with incomes up to $148 \%$ FPL (plus some $\$ 13,640$ in savings) can apply for extra help (Medicare.gov). The gap is to be closed by 2020, although a $25 \%$ rate always applies. Before the ACA the gap was from $\$ 2,800$ to $\$ 4,550$ with a $100 \%$ out of pocket.

29. For more details on the loss of public opinion support during the Clinton reform attempt, see Jacobs and Shapiro (2000).

30. AHIP (America's Health Insurance Plans), AMA (American Medical Association), PhRMA (Pharmaceutical Research and Manufacturers of America), AHA (American Hospital Association), the Chamber of Commerce.

31. 'Big government' is an embedded notion, a code word. It encloses a whole rhetorical and ideological construct, but only a brief explanation will be given here. It builds on the idea, promoted by conservatives/Republicans, that social policies are a way for the Democratic Party/ liberals to cater to undeserving minorities, who prefer to live in idleness and moral decrepitude. The argument goes that these social policies are financed through taxes on deserving hardworking whites. This rhetoric clearly builds on Barry Goldwater's famous 1964 acceptance speech 
at the Republican National Convention but has most markedly been promoted by Ronald Reagan. The use of code in racially-divisive discourse is best demonstrated by Tali Mendelberg (2001), Thomas Byrne Edsall and Mary D. Edsall (1991:12, 19, 71, 138); Terry Brimes (2003: 66). Moreover, 'Big government' challenges the legitimacy of federal state intervention and advocates more state responsibilities. Especially in Reagan's ideology, government should be nearly non-existent at a federal level, save for the military. Everything else should be handled by the states. See Hugh Heclo (27-9).

32. Health Care for American Now! is a progressive activist group gathering a number of smaller progressive groups such as American Friends Service Committee (Quakers), MoveOn, Planned Parenthood, True Majority, USAction, and others.

33. Public option was the idea that states would have the possibility to offer a government-run health care insurance that would have competed with private insurances.

34. Most famously among them: Max Baucus himself, Ben Nelson (Nebraska), and Blanche Lincoln (Arkansas). The Democrats had only a very narrow 60-seat majority (including 2 independents) in the Senate allowing them to override a Republican filibuster. This narrow majority gave conservative Democrats in the Senate disproportionate power since every Democratic voice was dearly needed. Moreover, the death of Senator Kennedy during that period made them lose the majority. Although the public option was defeated, a crippled leftover survived. The ACA allows state to provide government health care plans for low-income Americans not eligible for Medicaid: ACA. Section 1, Title 1, Subtitle D "Available Coverage Choices for All Americans" PART IV-STATE FLEXIBILITY TO ESTABLISH ALTERNATIVE PROGRAMS Sec. 1331. State flexibility to establish basic health programs for low-income individuals not eligible for Medicaid.

35. The health exchanges are websites that allow people to compare offers and find the best offer for their insurance needs.

36. Bart Stupak, Democratic representative from Michigan, was the driving anti-abortion force in the House. He managed to mobilize enough conservative Democrats to seriously jeopardize the reform. He had the support of the U.S. Conference of Catholic Bishops that favored universal coverage, but opposed the health reform because of abortion. Pro-choice Congressional Democrats, despite their threat not to support the bill, in the end chose the overall well-being of women instead on insisting on abortion coverage.

37. Patient Protection and Affordable Care Act Title II, Subtitle A, sec. 2001.

38. As of 2016, 19 states ( 23 in 2014) had not yet adopted the Medicaid extension (Kaiser Family Foundation 2016c). The legislatures of these states are all under Republican control, except for Maine (split control) (“State and Legislative Partisan Composition" 2016).

39. Alabama, Florida, Georgia, Idaho, Kansas, Maine, Mississippi, Missouri, Nebraska, North Carolina, Oklahoma, South Carolina, South Dakota, Tennessee, Texas, Utah, Virginia, Wisconsin, and Wyoming.

40. These calculations are based on "Population Estimates" (Census 2015).

41. Unfortunately the Census income brackets do not allow for a very close analysis as the second lowest income bracket comprises incomes from $\$ 15,000$ to $\$ 24,999$, thus including a small proportion of persons who would qualify for the Medicaid extension at 133\% FPL. In 2015 the FPL was $\$ 11,770$. Incomes up to $133 \%$ FPL are therefore $\$ 15,654$, thus including a very small share of incomes in the second lowest income bracket. However, because the excess over the lowest income bracket was so small, less than $\$ 1,000$, it was preferable not to include the second-lowest income bracket.

42. It must be pointed out that the eligibility levels for the classical Medicaid in these states vary tremendously. The lowest eligibility levels for parents and caretakers in 2016 was the level in Alabama at $13 \%$ FPL. 
43. Despite the prohibition for undocumented immigrants to purchase coverage through the health exchanges, the ACA supports clinics that provide free care for illegal immigrants. It is supposed that mainly illegal immigrants use the Medicaid emergency programs. A study of the population using Medicaid emergency in North Carolina between 2001 and 2004 found that $99 \%$ of the users of Medicaid emergency were illegal immigrants (DuBard and Massing 1085-92). Legal immigrants, however, are covered and subsidized through the ACA. But legal immigrants with less than 5 years of residence in the US are not eligible for Medicaid.

44. The Cadillac Tax or Excise Tax would have applied to plans that cost more than $\$ 10,200$ for individuals and $\$ 27,500$ for families. The plans exceeding this threshold would have been taxed at $40 \%$. This was also a means to rein in some previous tax exclusion where the most expensive plans provided for the highest-income employees obtained the highest subsidies through tax exclusion. Such privileges contribute to the hidden costs of the health system.

45. Unions denounce the employer mandate, for example. According to them it leads employers to shift their workers on part-time contracts, because only full-time employees must be covered under the employer mandate. Unions denounce the double loss of income and health benefits. Another aspect that is denounced concerns the increase of premiums because of expanded health coverage, such as no annual or lifetime limits, coverage of children up to age 26 , and more benefits in the plans.

46. It must be added that a better argument was made to defend the Frontier Amendment.

47. The case is slightly different for Republicans. The 2003 Medicare reform is a good example. The expenditures were not covered, but the bill was passed nonetheless. The 2003 Act added, at the time of the enactment, an estimated $\$ 395$ billion in spending (the Congressional Budget Office readjusted this estimation to $\$ 534$ billion in 2004), for the changes made through Medicare advantage and Part D (drug coverage). The reform was unfunded (meaning the taxpayer had to pick up the bill) and contained no cost-containment for drugs because this was contrary to conservative ideology. Especially the subsidies for Medicare Advantage, Medicare plans managed by private insurers, have been called "corporate welfare." Arguments about costs seem to apply only to Democrats, not to Republicans (Bartlett; Oliver et al.; Kaiser Family Foundation 2016a).

48. CBO.gov: the Congressional Budget Office is a non-partisan commission charged with the financial examination of bills. $\mathrm{CBO}$ approval of a bill is paramount in assuring its survival and enactment.

49. Martin Gilens explains this perception of the poor as being racial minorities. Especially since the 1960s, the media have increasingly represented poverty with a black face. The proportion of reports on poverty illustrated with black faces exceeds the proportion of blacks among the poor.

50. In 2010 , about $29.2 \%$ of whites and $40.5 \%$ of blacks were eligible for those subsidies (Census 2012).

51. For more details on the white backlash against social policies and the subsequent political exploitation of this backlash by Ronald Reagan in particular, see Edsall and Edsall (1991).

52. Some classical references to racial minorities exist in the ACA, most of which consists in applying existing rules and regulations to the ACA provisions. For example, in making awards for the enhancement of health care and workforce training, among the listed priorities are common affirmative action-type clauses in choosing the benefitting institutions, such as Sec. 5312: "have a record of training individuals who are from underrepresented minority groups or from a rural or disadvantaged background;“ Title V, subpart D Sec. 5312.

53. Title X Strengthening Quality, Affordable Health Care for All Americans. Part III Indian Health Care Improvement, Subtitle C, Sec.10334 Minority Health. Although this section is buried in the part devoted to Native American health, the Office for Minority Health monitors all racial minorities.

54. The backlash against race-specific policies started in the late 1970s and is still lively today, as is exemplified by the recent affirmative action ban in Michigan (2014). 
55. France has a law favoring women (Loi sur la parité) compelling political parties to present as many women as men for elections. The results are less than convincing. Boéton explains that racial targeting is taboo in France, however, although some measures are comparable to affirmative action. She cites programs like ZEPs (Zones d'Education Prioritaire, a program adopted in 1981) that are chosen according to a local deficit in cultural, social, and economic capital among the population. Schools in such areas are entitled to additional funding and extra teachers, for example. Basically, the state targets the problems, since it is not allowed to target a racial or ethnic population. Similar programs exist in business and urban areas since 1986. The UK adopted the Equality Act in 2010 and preferred to call it 'positive action'. While the act encompasses minorities, government insists on the need to combat the effects of sexism. Government also highlights the fact that the act promotes more equality for homosexuals. Moreover, it allows, but does not require, enterprises to take positive action (positive discrimination and quotas remain prohibited). See "Equality Act" (2010).

56. Anderson argues that the economic inequalities are still so deep between the black and white populations that race-specific, affirmative action type policies are still justified. However, William Julius Wilson argues that this applies only to a certain extent. In 1978, he famously argued that affirmative action was not efficient enough, especially to address the needs of the socalled "underclass." He favors race-neutral, but issue-focused policies. However, in 2010 he started to plead for the maintaining of affirmative action, which he deems necessary to secure the black middle-class (Wilson 2012).

57. See for example Cornel West $(1993,2009)$. Both advocate this strategy for reasons of political feasibility.

58. Wilson makes a detailed argument of this in The Declining Significance of Race (2012). After this pioneering work, others have picked up the same argument, Obama among them.

59. In $201020.8 \%$ of blacks had no health insurance, compared with $11.7 \%$ of whites and $30.7 \%$ of Hispanics.

60. France, for example, refuses to establish racial statistics arguing that it would be discriminatory. This point is certainly debatable, for it makes it impossible to assess the extent of inequalities and the effect of discrimination.

61. Obama discusses problems and grievances of the black and Hispanic population in a whole chapter in The Audacity of Hope. His account of his experience as a community organizer in this autobiography shows that he has a great awareness of the problems faced by the black population.

62. See any of the reports produced by the US Census Bureau or any other administration, such as the reports cited above. Among the first government-ordered reports were the Moynihan Report (1965) and the Kerner Report (1968), both describing the seriousness of the situation. The US Department for Health and Human Services coordinates several health agencies. Among the major agencies are: The National Institutes of Health, The Center for Disease Control, and The Office for Minority Health. The latter pays especially attention to racial disparities, but all establish statistics by race and ethnicity.

63. In $2010,49.7 \%$ of the black population was in the two lowest income quintiles (up to $\$ 35,000$ ) compared with $31.5 \%$ of the white population belonging to the two lowest quintiles (Census 2012).

64. The Medicaid extension to up to 133\% FPL (if all states applied it) could benefit $17.2 \%$ of the black population (as compared with $5.9 \%$ of the white population.) (U.S. Census Bureau, 2006-2010 American Community Survey).

65. However, the inadequacy of the funds is also denounced. See Gordon Schiff and Claudia Fegan (2003: 307-11).

66. The overall death rate for blacks in 2010 was 958 per 100,000 , as compared with 760.2 per thousand for the total population, 763.3 per 100,000 for whites, and 546.1 per 100,000 for 
Hispanics. For many selected causes of death black rates are much higher than for other populations. For example: (in per 100,000) for diseases of the heart, the black rate was 247.3 compared with 191.4 for whites or 136 for Hispanics. For malignant neoplasms it was 215.5 for blacks, compared with 182.3 for whites and 116.2 for Hispanics. Other stark differences concern diabetes mellitus. The black death rate was 42.8, compared with 19.8 for whites and 28.9 for Hispanics. The contrast is even more frightening for HIV. The black death rate was 17.3 compared with 1.5 for whites and 4.1 for Hispanics.

67. CDC. Division of HIV Prevention. 29 Apr. 2015. Consulted 12 Feb. 2016. CDC. "Diabetes Public Health Resource," Center for Disease Control and Prevention. 5 Sept. 2014. In 2012 blacks represented $41 \%$ of the HIV infected population but they only represent $12 \%$ of the total population, compared with whites making up $34 \%$ of the HIV population but representing $63 \%$ of the total population. The diabetes rate for black males was $9.7 \%$ in $2010,9.3 \%$ for black females, compared with $6.6 \%$ for white males and $5.4 \%$ for white females.

68. The rates in 2012 were 51.5 per 1000 for blacks and 23.5 per 1000 for whites. Blacks and Hispanics together accounted for $57 \%$ of all teen pregnancies in 2012.

69. In 2009 the rates for blacks were 12.4 per 1,000 live births, compared to a rate of 6.6 for the total population and 5.5 for whites. Among the OECD countries, the US had the highest infant mortality rate in 2010 with 6.1 compared to the lowest rate of 2.3 for Finland, or 3.4 for Germany and 3.6 for France (MacDorman et al. 1).

\section{ABSTRACTS}

This article examines the particularities of the 2010 Patient Protection and Affordable Care Act (ACA) in a historical comparative perspective. Comparisons are made to highlight the specificities of the American welfare state and of health legislation in particular. The comparisons with European countries aim at highlighting the particularity of racial division among the American working and middle class that hampered the expansion of the American welfare state and how this impacted the ACA. Despite certain shortcomings resulting of the idiosyncrasies of America's welfare state and political system (the single payer system was not considered, Medicaid expansion is now optional, a market-based system), the ACA nonetheless managed to circumvent some problems due to the racialization of social policies and found ways to address some of the needs of minority populations by targeting specific issues that are particularly problematic for those populations.

Cet article analyse les particularités du Patient Protection and Affordable Care Act de 2010 (ACA) dans une perspective comparatiste et historique. Les comparaisons servent à mettre en lumière les spécificités de l'Etat providence états-unien et en particulier de la législation en matière de santé. Les comparaisons servent à mettre en évidence la particularité de la division raciale parmi la classe ouvrière et la classe moyenne qui a freiné le développement de l'Etat providence aux Etats-Unis et comment cela s'est répercuté sur l'ACA. Malgré certains défauts résultant de l'idiosyncrasie de l'Etat-providence et du système politique états-unien, tels que l'abandon du single payer system à la canadienne ou encore le fait que l'extension de Medicaid soit devenue optionnelle, ou un système de santé fondé sur le marché, le ACA a réussi tout de même à contourner certains problèmes causés par la racialisation des politiques sociales et à répondre à 
certains besoins des populations minoritaires en ciblant des problèmes spécifiques affectant principalement ces populations.

INDEX

Mots-clés: Affordable Care Act, politiques sociales, Obama Barack, comparatiste, racialisation, États-Unis

Keywords: Affordable Care Act, social policies, Obama Barack, comparative, racialization, United States

\section{AUTHOR}

\section{LEA STEPHAN}

Lea Stephan is a $4^{\text {th }}$ year PhD candidate and ATER, at the CAS EA 801 of the Universite ToulouseJean Jaurès. Dissertation title: Social Policies and Racial Questions: From the Great Society to Obamacare. Advisors: Anne Stefani and Françoise Coste. Contact: Lea.stphn [at] gmail.com 